\title{
Review
}

Punyasloka Pattnaik*, G.S. Dangayach and Awadhesh Kumar Bhardwaj

\section{A review on the sustainability of textile industries wastewater with and without treatment methodologies}

https://doi.org/10.1515/reveh-2018-0013

Received February 17, 2018; accepted May 2, 2018

\begin{abstract}
The textile industry in India plays a vital role in the economic growth of the nation. The growth of the textile industry not only impacts the economy of a country but also influences the global economy and mutual exchange of technology between the countries. However, the textile industry also generates an enormous quantity of waste as waste sludge, fibers and chemically polluted waters. The chemically polluted textile wastewater degrades the quality of the soil and water when it mixes with these natural resources and its dependent habitats and environment. Owing to the existing problem of solid and liquid waste, textile industries are facing major problems in environment pollution. Therefore, researchers and the textile industries are focusing on the reduction of textile wastewater and the formulation of alternative efficient treatment techniques without hampering the environment. Hence, the present literature survey mainly concentrates on the various wastewater treatment techniques and their advantages. Moreover, the focus of the study was to describe the methods for the reduction of environmental waste and effective utilization of recycled water with zero wastewater management techniques. The alternative methods for the reduction of textile waste are also covered in this investigation. Finally, this paper also suggests utilization of solid wastes after treatment of wastewater in other sectors like construction for the preparation of low-grade tiles and or bricks by replacing the cement normally used in their manufacturing.
\end{abstract}

Keywords: cost-benefit analysis; locking tiles/bricks; textile wastewater; treatment.

*Corresponding author: Punyasloka Pattnaik, Department

of Management Study, MNIT Jaipur-302017, India,

E-mail: punyasloka2010@gmail.com

G.S. Dangayach and Awadhesh Kumar Bhardwaj: Department

of Management Study, MNIT Jaipur-302017, India; and Department

of Mechanical Engineering, MNIT Jaipur-302017, India

\section{Introduction}

This review paper seeks to describe, clarify, evaluate and/ or integrate the content of primary and previous published reports on various treatment techniques for the recovery of wastewater as collected from textile industries. The study also describes the methods for effective utilization of wastewater by low cost techniques using various industrial wastes as an absorbent for effective treatment of textile wastewater. An intensive research was conducted to develop an understanding of low cost treatment techniques for the successful use of various textile wastes. Therefore, the present study reviews the following issues and finally proposes the best alternative.

\section{Study on the different purification techniques for the treatment of textile wastewater}

The real problem behind industrial textile wastewater is that it is extremely carcinogenic in nature, it causes allergies and it produces toxic compounds in addition to other environmental issues. Textile dyes have a high importance due to being colourful, in addition different dyes have different significance in individual societies and their use is a significant concern in the modern world. However, these textile dyes, after cleaning or washing of textile fibers after the color is added produce huge environmental pollution. The wastewater contains not only the colored dye but also other metallic particles, high fluctuating $\mathrm{pH}$, suspended solids with high chemical oxygen demand (COD), etc. $(1,2)$. Therefore, today, the textile wastewater from the textile and dyeing industries causes major concern with regard to the treatment of textile wastewater. This is reused for textile processing because of the high quantity of biological oxygen demand (BOD), $\mathrm{pH}$, color, COD and the existence of solid metal particulates (3-7). However, 
other researchers have also reported on the toxicity of wastewater effluents by way of biological systems and attempted to reduce the toxic effect $(8,9)$.

Jeihanipour et al. (10) proposed an original process for the production of biogas from cellulose in blended waste textiles fibers and in the solvent, N-methyl morpholine-N-oxide used for pretreatment of cellulose. They reported that the cellulosic part of the waste separated from the noncellulosic fibers using the proposed $\mathrm{N}$-methyl morpholine-N-oxide method. Foo and Hameed (11) discussed new technologies in waste treatment along with challenges facing the time of treatment of dyes and pointed out its future consequence. They reported that dye processing industries or sectors specifically involved in textile generation might fail in the future if there is no environmental pollution control. They also suggested that adoption of titanium dioxide accommodation oxidation was capable of being used as a fundamental approach for wastewater treatment and detoxification of the processes that recover the catalyst from the slurry stream $(12,13)$.

Barredo-Damas et al. (14) suggested an ultrafiltration process that may be an alternative for the pre-treatment of textile wastewater through membrane separation processes such as nanofiltration and a reverse-osmosis process, respectively, with $99 \%$ turbidity with $82-98 \%$ of the color being removed along with COD also being reduced between 62 and 79\% successfully. However, in a conventional process for wastewater treatment mainly physicochemical and biological treatments by activated sludge method were frequently used but after treatment the same wastewater could not be reused in the textile processing sectors (15-21) (Table 1).

Ashwin et al. (23) studied textile liquid wastewater treatment using the sequential batch reactor (SBR) technique and performed the pre- as well as post-treatment using a sonochemical reactor. They observed that in this method the treatment process, the effluent was vigilantly diluted to get the desired chemical oxygen demand concentration, but the cost can be successfully managed by using the SRB technique with pre- as well as post-treatments. Similarly, few researchers used the bioaugmented membrane bioreactor (MBR) (24), the anaerobic batch reactor (25) and the bioreactor typology technique (2628). However, the acidogenic reactor, the methanogenic reactor (29), the recycle reactor (30), the photoelectrocatalytic reactor (31), toxic reactive Blue Bezaktiv S-GLD 150 dye (32) and the fixed bed reactor (33) for the removal of total organic carbon (C).

Khlifi et al. (34) reported that de-colorization and de-toxification of textile waste water using laccase from Trametes trogii and investigated in the absence of laccase mediators. They observed that laccase was not able to decolorize the effluent, where the enzyme concentration was slightly higher. Again, Khouni et al. (35) studied three different processes to observe the decolorization efficiency of textile effluent from laboratory prepared waste water consisting of two different reactive dyes and found that in the coagulation/flocculation method $93 \%$ of color was removed whereas, commercial laccase catalysis reduces the color by $99 \%$, respectively.

Similarly, most of the researchers repeatedly cited their research work in different platforms as regards the dye removal process, such as the membrane separation process, reverse osmosis, the coagulation technique, chemical oxidation demand, the electrochemical process, the aerobic and anaerobic microbial degradation process, respectively, which were successfully implemented in the textile industry. However, all the techniques were not costeffective, and these methods have a lot of restrictions for successfully removing color from wastewater efficiently (36, 37). For example, Merzouk et al. (38) investigated both the mixed wastewater and textile wastewater on the treatment of pure red dye solution using the electrocoagulation technique (39) and observed that textile wastewater was not fully treated whereas, pure red dye solution was suitable with the higher level of color and organic pollution abatements. Finally, they proposed that a more accurate evaluation technique was needed to improve the treatment efficiency of the mixed wastewater. Similarly, other industries like the food industry $(40,41)$, tanneries (42, 43), heavy metals (44-47), mechanical workshops $(48,49)$, polymerization manufacture and the textile

Table 1: Conventional techniques adopted to treat the wastewater (3-21).

\begin{tabular}{lll}
\hline Sl. No & Types of techniques & Treatment \\
\hline 1 & Physical & Sedimentation, screening, aeration, flotation and skimming, filtration, degasification and equalization \\
2 & Chemical & Chlorination, ozonation (22), neutralization, coagulation, adsorption and ion exchange \\
3 & Biological & Activated sludge treatment methods, trickling filtration, oxidation, ponds, lagoons, aerobic digestion \\
& a. Aerobic & Anaerobic digestion, septic tanks, lagoons \\
\hline
\end{tabular}


industries (50-53) followed the electrocoagulation treatment technique specifically in highly polluted industrial wastewater locations. Hence, based on the mentioned techniques for the treatment of textile wastewater, very few treatment techniques have been used efficiently in the textile industry. Therefore, there has been development in the demands for the making of textile dyes; an inexpensive method is required with minimum chemical and energy consumption. Nowadays, the electrocoagulation technique is frequently used by the textile industry (54). The electrocoagulation technique is a simple and efficient method applied in most of the wastewater treatment plants. The wastewater generally contains oil wastes $(48,55)$, textile wastewater $(56)$, dye (57-60), foodstuff waste (61), heavy metals (62-65), fluoride and polyvinyl alcohol (66), for the removal of Bomaplex Red CR-L (67) by the electrocoagulation process. These authors successfully removed color by coagulation and flocculation technologies (68), respectively.

Similarly, biological treatment processes treat textile effluent by reverse osmosis (RO) $(69,70)$ and nanofiltration membranes (71-75) for reuse of water and it was also observed that reverse osmosis and nanofiltration membranes could successfully remove COD, BOD and color from the biologically treated effluents. Similarly, removal of metal ion mixtures (i.e. textile dye and metal ion) and dye decolorization is also possible using the electrochemical treatment process. It was also explained, by using this technique rapid decolorization could also be achieved by complete reduction of both acid dyes and the reactive dyes (76). Lastly, it was proposed that the electrochemical treatment process was one of the efficient techniques to remove binary mixtures and textile dye decolorization, respectively. However, a limitation of this technique was that it was unable to mineralize the organic pollutants and other by-products completely (77).

Again, nowadays most researchers are mainly focused on various microorganisms (78-80) which degrade azo dyes (81-85) in two different conditions, anaerobic and aerobic, respectively (86-91). Hence, based on the impact of azo dye one of the efficient treatment processes specifically for textile wastewater treatment, Cui et al. (92) reported that the azo dye decolorization rate was higher with the use of consortia as compared with other individual strains. Bacterial consortia can be decolorized by methyl red under aerobic and anaerobic conditions, respectively (93-96). Similarly, Eren (97) reviewed more than 100 research papers on ultrasonic treatment process with biochemical, electrochemical, photolysis and photocatalysis, respectively (98-100). Whereas, Fenton (101, 102), electro-Fenton (103) and azonation processes, respectively, used specifically for textile dyes and dye baths due to the cavitation phenomenon occurs which increases the efficiency of advanced oxidation processes (AOPs) (104-108).

Wang and Peng (109) discussed the scientific utilization of natural zeolites as adsorbents for the purification of wastewater and water obtained from the textile dye industry, municipality waste or treatment plants' wastewater, respectively. They also reported that the modified zeolite shows better adsorption capacity specifically for organic material and anions. Similarly, Hedström and Amofah (110) studied natural zeolite such as clinoptilolite which has a maximum adsorption capacity for ammonium of about $20 \mathrm{mg} / \mathrm{L}$ with a maximum grain size of 4-8 $\mathrm{mm}$. They also estimated that for smaller grain size the adsorption capacity was more as compared with other natural zeolites like natural Bulgarian zeolite treatment (111-118), zeolite-clinoptilolite (119), bentonite (120, 121), sepiolite (122), zeolite (123), used to remove color $(124,125)$ from aqueous solutions.

Martellini et al. (126) collected wastewater from two different plants, textile wastewater and municipal wastewater, to obtain the concentrations, compositional profiles and contribution to ambient levels and observed that polybrominated-diphenyl-ethers concentration was higher in textile wastewater. They also proposed that the plant's distance from the source and the wind direction also affect the environment. Loncar et al. (127) discussed cheap enzyme sourced from potato polyphenol oxidase for decolorization of seven different textile dyes and three different dye effluents and reported that the optimized conditions were achieved for removal of dyes of about 93-99.9\%. Finally, potato polyphenol oxidase was recommended as being capable of extracting reactive dyes and effluents without any intermediate effects and that decolorization (128) was obtained via insoluble polymers using filtration.

Derden and Huybrechts (129) determined a new technique for the reduction of decabromodiphenyl ether (Deca-BDE) emissions from the textile industry. Nowadays, BDE is increasingly used in the textile industry for the production of cotton and synthetic fibers for clothing and carpets. Brominated flame retardants have been used to protect fibers from burning without depending on the texture, color as well as the appearance of the prepared fabrics (130). Hence, during the finishing process larger amounts of Deca-BDE were being mixed with the textile wastewater and was harmful to the environment as well as the soil. Therefore, the additional technique was identified as emission levels associated with the best available technique (BAT-AEL) as another parameter, which confirmed 
that the emission data with the determined BAT-AEL range was less than $20 \mathrm{mg} / \mathrm{L}$. Table 2 indicates a summary of various textile industries treatment techniques and other alternative techniques for textile wastewater.

\section{Study on the effective utilization of low-cost absorbent for the treatment of textile industrial effluents}

Again Mahmoued (131) proposed another wastewater treatment method for coal filter treatment of textile industry effluents. In this techniques cement kiln dust (CKD) and $\mathrm{CKD} /$ coal filters remove color, heavy metals, organic substances and turbidity from textile wastewater by hydraulic loading of $1 \mathrm{~m}^{3} / \mathrm{m}^{2} \mathrm{~h}$. However, using the CKD/coal filters method, the percentage of removal was more as compared with the CKD filter technique. Saraya and Aboul-Fetouh (132) investigated the process of elimination of acid dyes as well as dye colored by using CKD from aqueous solution and then the dye concentration was measured using ultraviolet-visible (UV-Vis) spectroscopy before and after treatment. Whereas, the X-ray diffraction (XRD), infra-red (IR) and differential scanning calorimeter (DSC) test were also performed to measure the colored residue. Finally, it was reported that CKD might be an efficient alternative technique to remove the acid dyes from the textile wastewater industries of Egypt. Mostafa et al. (133) proposed the ability of cement by-pass dust (CBPD), a by-product of the cement industry can decrease the COD, heavy metals and total suspended solids (TSS) within the acceptable limit from textile wastewater. They also demonstrated in different dose percentages of CBPD and observed that at a $2 \mathrm{~g} / \mathrm{L}$ dose CBPD was able to remove $75 \%$ of primary true color, $33.2 \%$ of heavy metals, $92.1 \%$ of TSS and $91.3 \%$ of COD from textile effluent. Mahmoued (131) studied the usefulness of both CKD and coal filter/CKD for the removal of BOD, COD, heavy metals, color and turbidity from textile wastewater specifically for the weaving and spinning industries of Egypt. The addition of coal filter in CKD was shown to have a better performance as far as the removal of heavy metals, color, turbidity and it reduced BOD, COD as compared with only passing through the CKD technique for textile wastewater. However, Mackie et al. (134) studied the physicochemical characterization of six different samples of CKD collected from across North American cement plants and produced calcium hydroxide $[\mathrm{Ca}(\mathrm{OH}) 2]$ slurries for the treatment of textile wastewater applications and finally compared these characteristics with commercially available quicklime products. They reported that commercially available quicklime and the slurry made from CKD samples preformed equally well, but a large quantity of raw material CKD was required for acid neutralization of the textile wastewater.

Saraya and Nassar (135) studied the adsorption of Reactive Blue 7 (136) dye as generated from textile wastewater using a low-cost adsorbent such as CKD by taking into consideration the use of contact time, dye concentration, and adsorbent dose, respectively. The maximum adsorption capacity of CKD was $100 \mathrm{mg} / \mathrm{g}$ of CKD at ambient temperature and they also reported that the treatment of dye-loaded CKD with different solvents and acids showed that a slight amount of dye was released in water, along with methanol and ethanol due to the physical adhesion of the dye. Whereas in the case of acid dye, the CKD was dissolved entirely, which may be the interaction of dye molecules with the CKD. Similarly, Shaheen et al. (137) studied the sorption nature of the four divalent metals, i.e. cadmium (Cd), copper $(\mathrm{Cu})$, lead $(\mathrm{Pb})$ and zinc $(\mathrm{Zn})$ in textile wastewater with three different sorbents such as CKD, sawdust and activated C $(36,138,139)$. Hence, most of the researchers preferred good absorbency along with being economically viable, such as agriculture waste (140) which can be used as a suitable adsorbent (114, 141, 142), tyre char (143), agricultural wastes such as rice bran (144), bone char (145) and fly ash (146, 147), respectively.

They observed that the average material removed from the textile wastewater was 100\% Cd which was extracted by using activated C and CKD, but nearly $75 \%$ of the $\mathrm{Cd}$ was eliminated using the sawdust medium. However, the combination of activated $\mathrm{C}$ and sawdust were not shown to have efficient sorption in nature for the removal of divalent metals from textile wastewater. Again, another group Refaey et al. $(148,149)$ studied CKD (a byproduct of cement) and activated C (obtained from the agriculture waste) as an adsorbent for the removal of $\mathrm{Cd}$ and $\mathrm{Cu}$ separately from aqueous solutions. The observed results indicated that CKD might be used as a low cost and efficient sorbent for removal of $\mathrm{Cd}$ and $\mathrm{Cu}$ from textile wastewater as compared to activated C. However, Kumar and Porkodi (150) used rubber wood sawdust instead of CKD for the removal of Bismarck brown from an aqueous solution by the adsorption process. Bismarck brown is used for hair colorants as well as shoe polish, however, when mixed with wastewater or with the environment it may be harmful to human life due to its carcinogenic nature. Hence, rubber wood sawdust can be successfully used as an adsorbent for removal of Bismarck brown from aqueous solutions. 


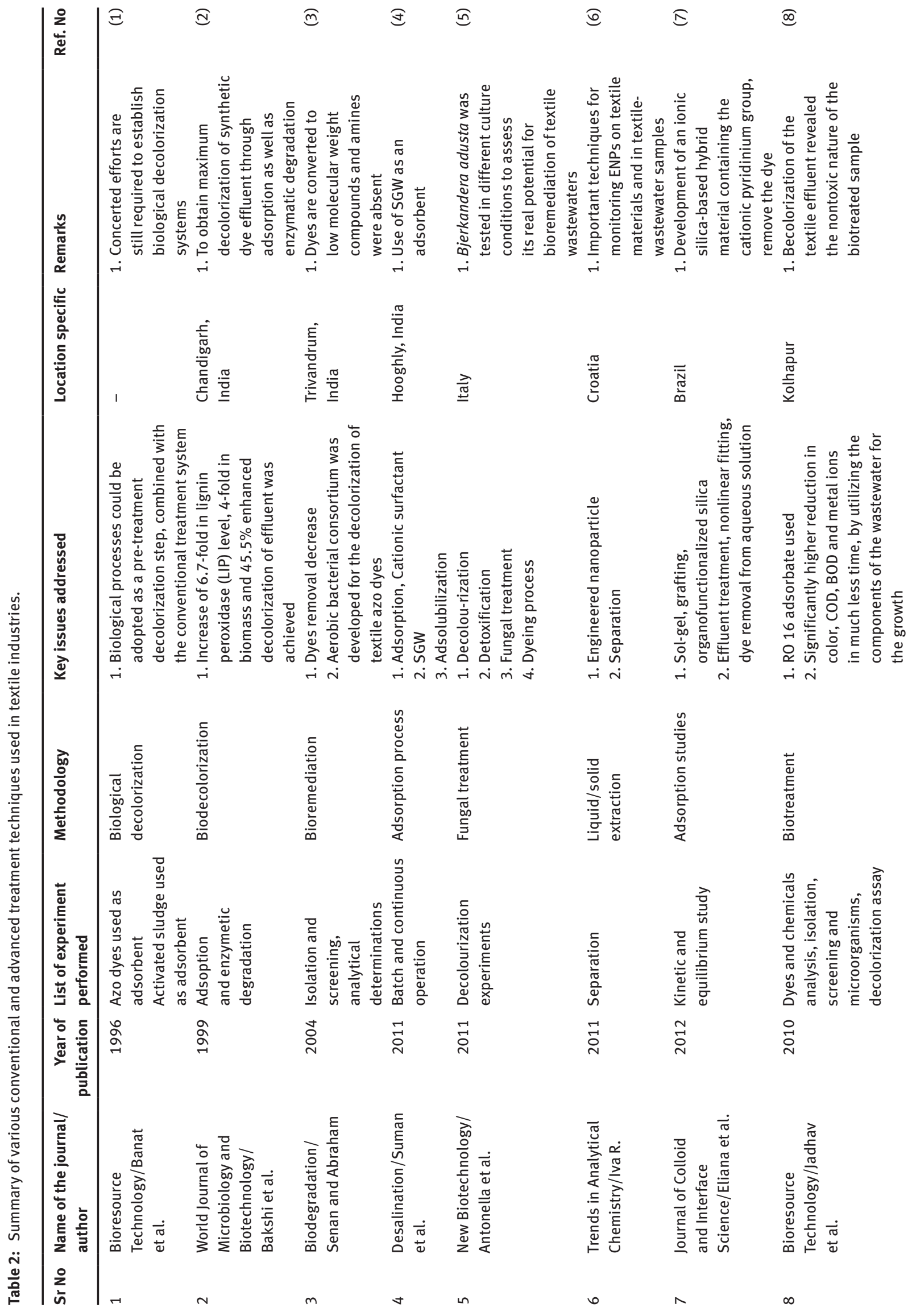




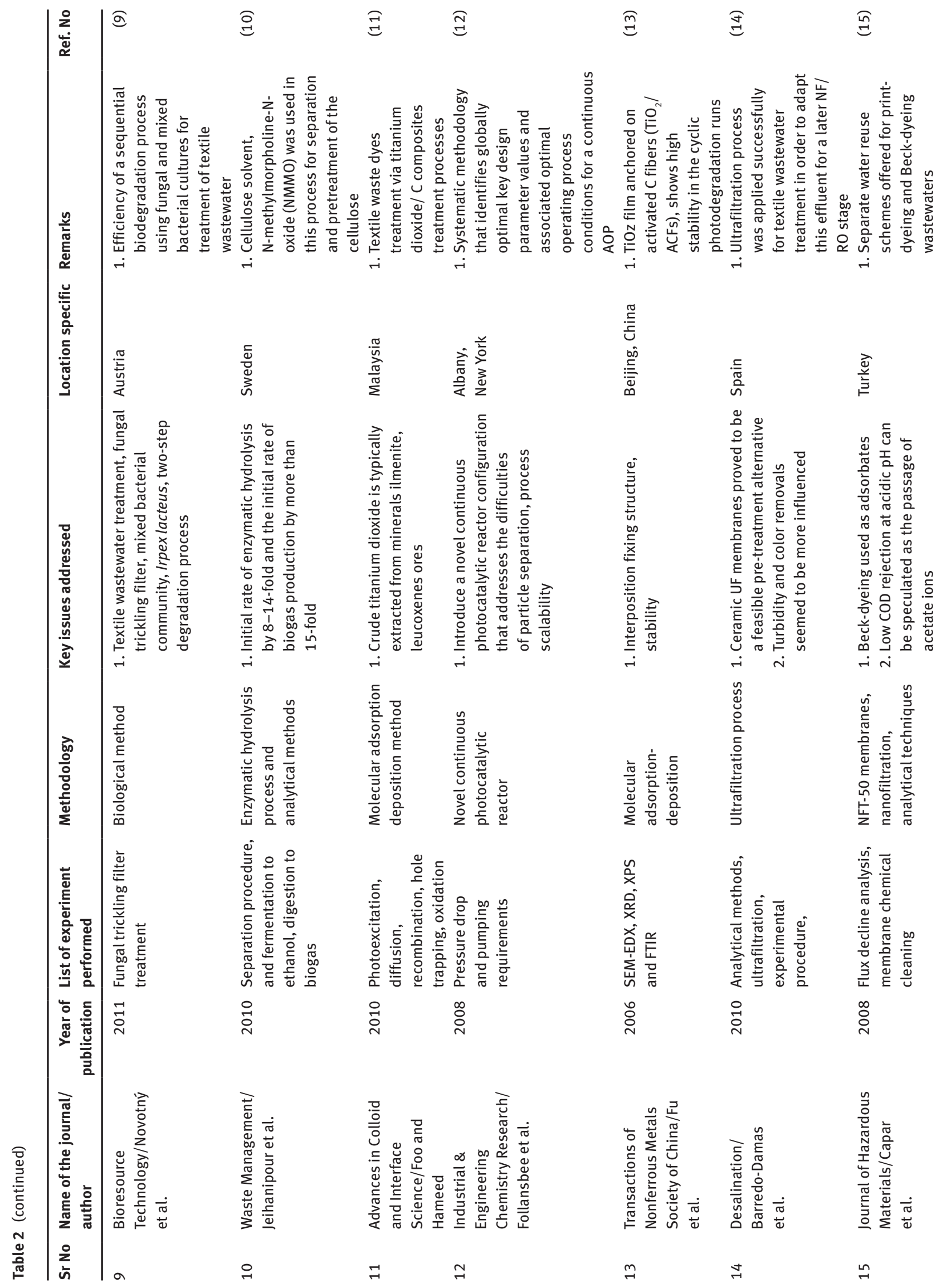




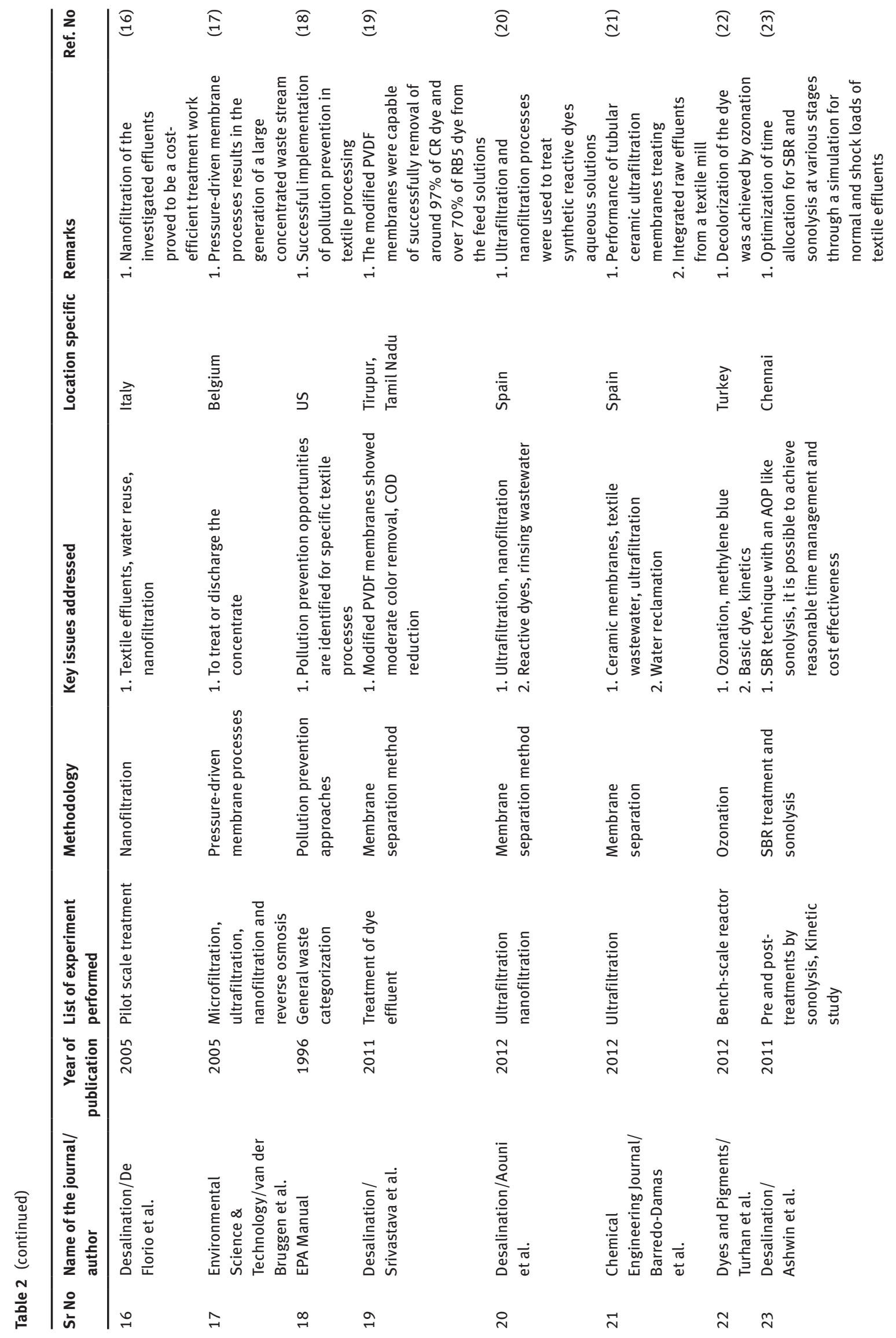




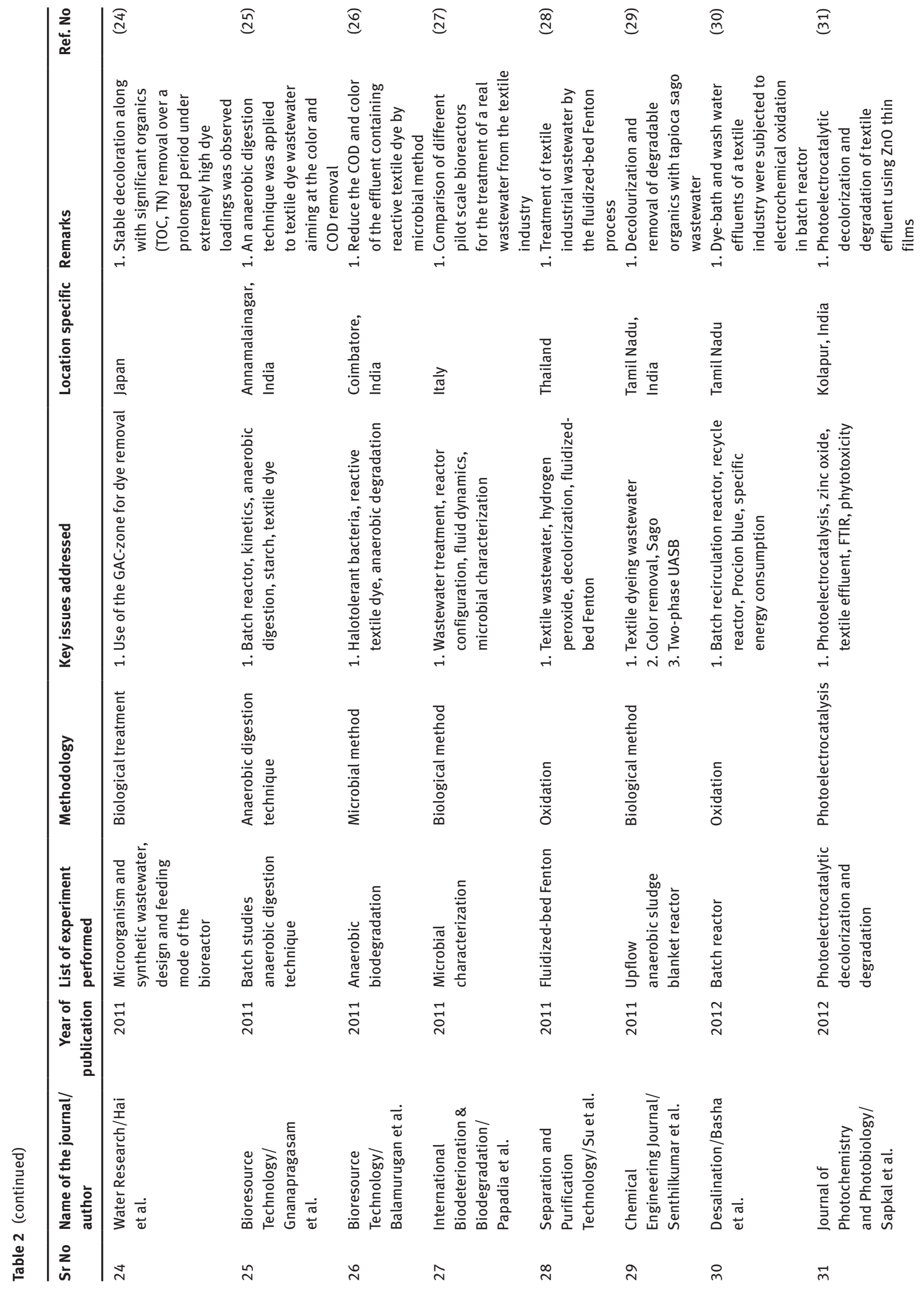




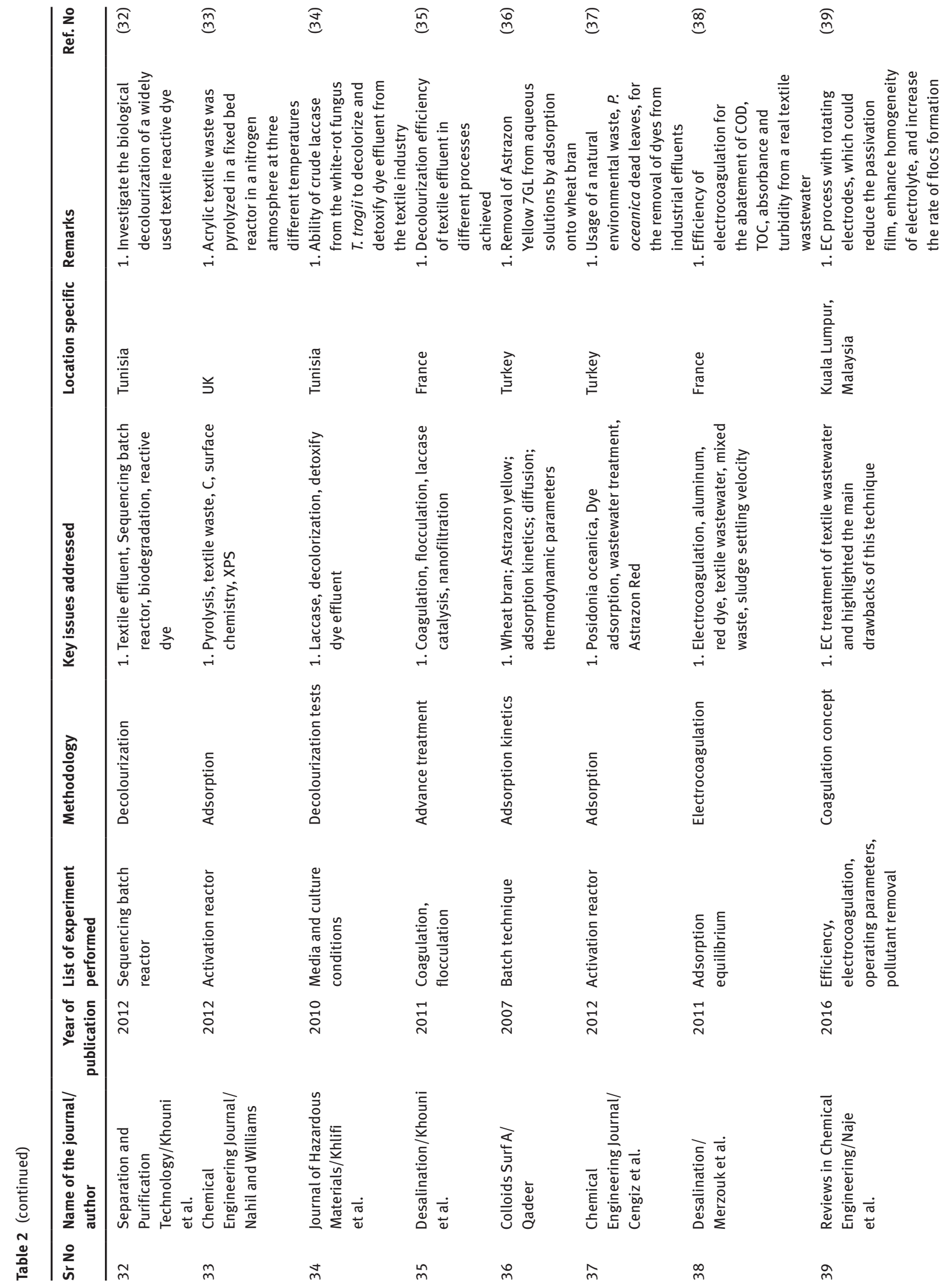




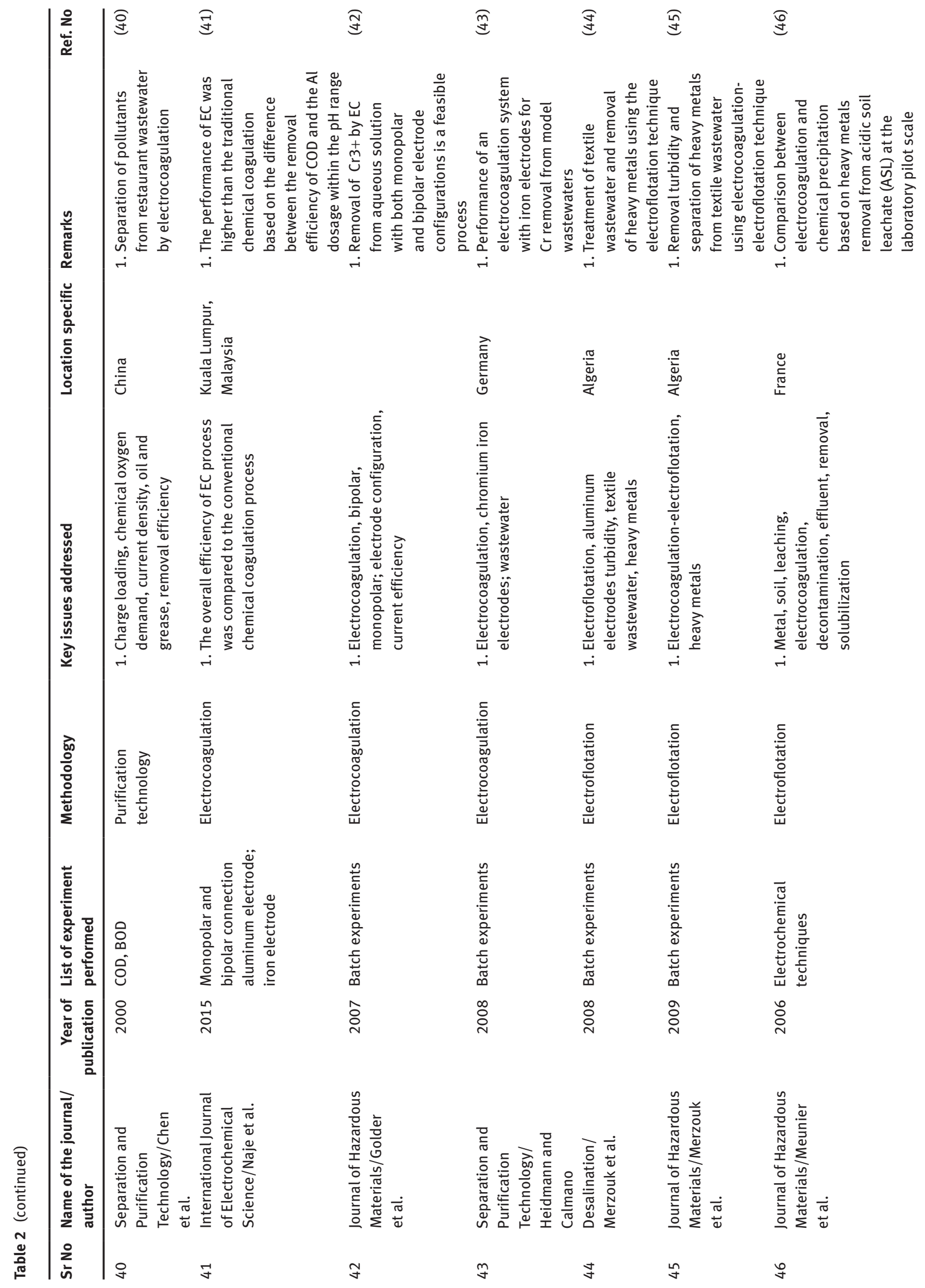




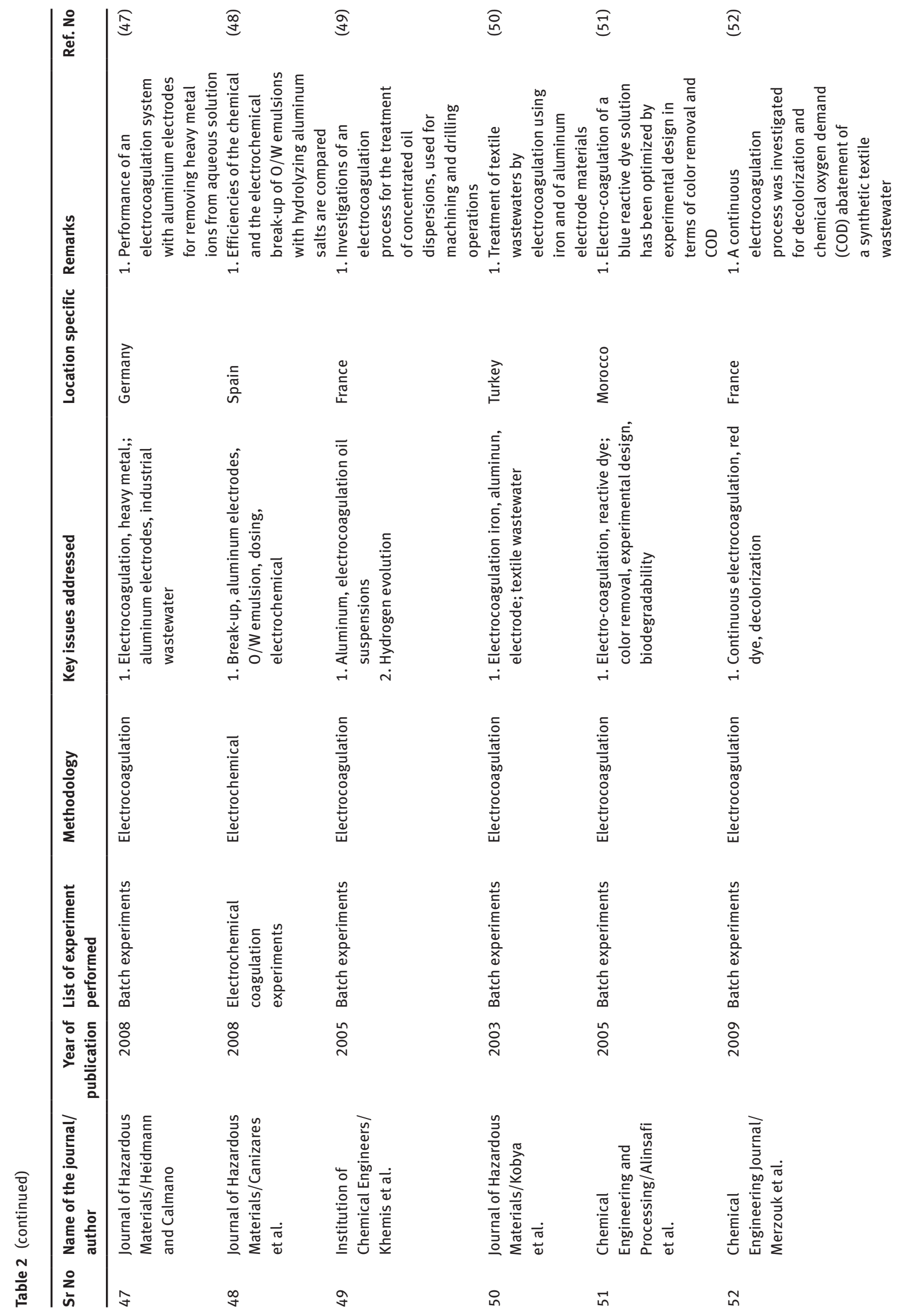




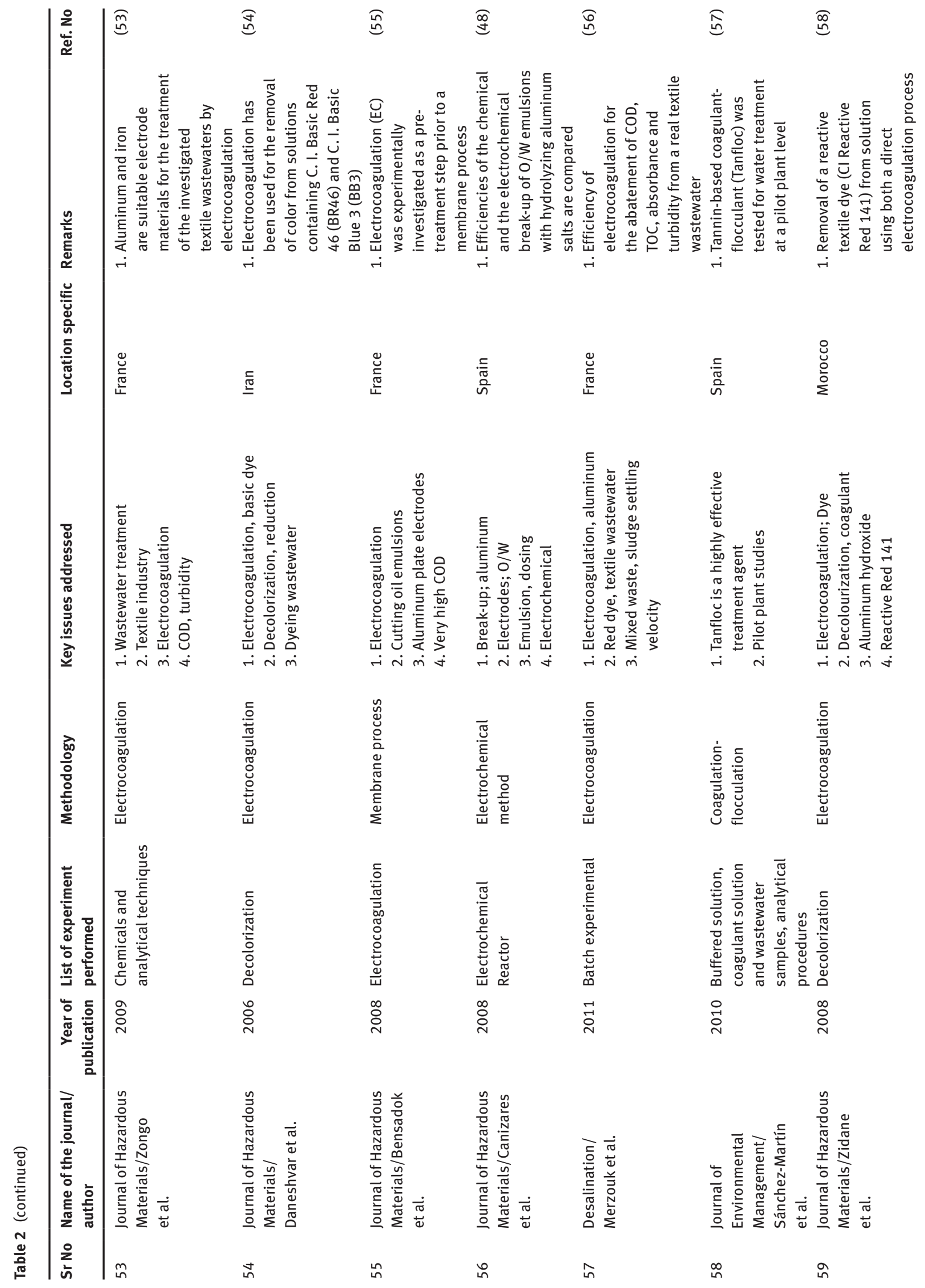




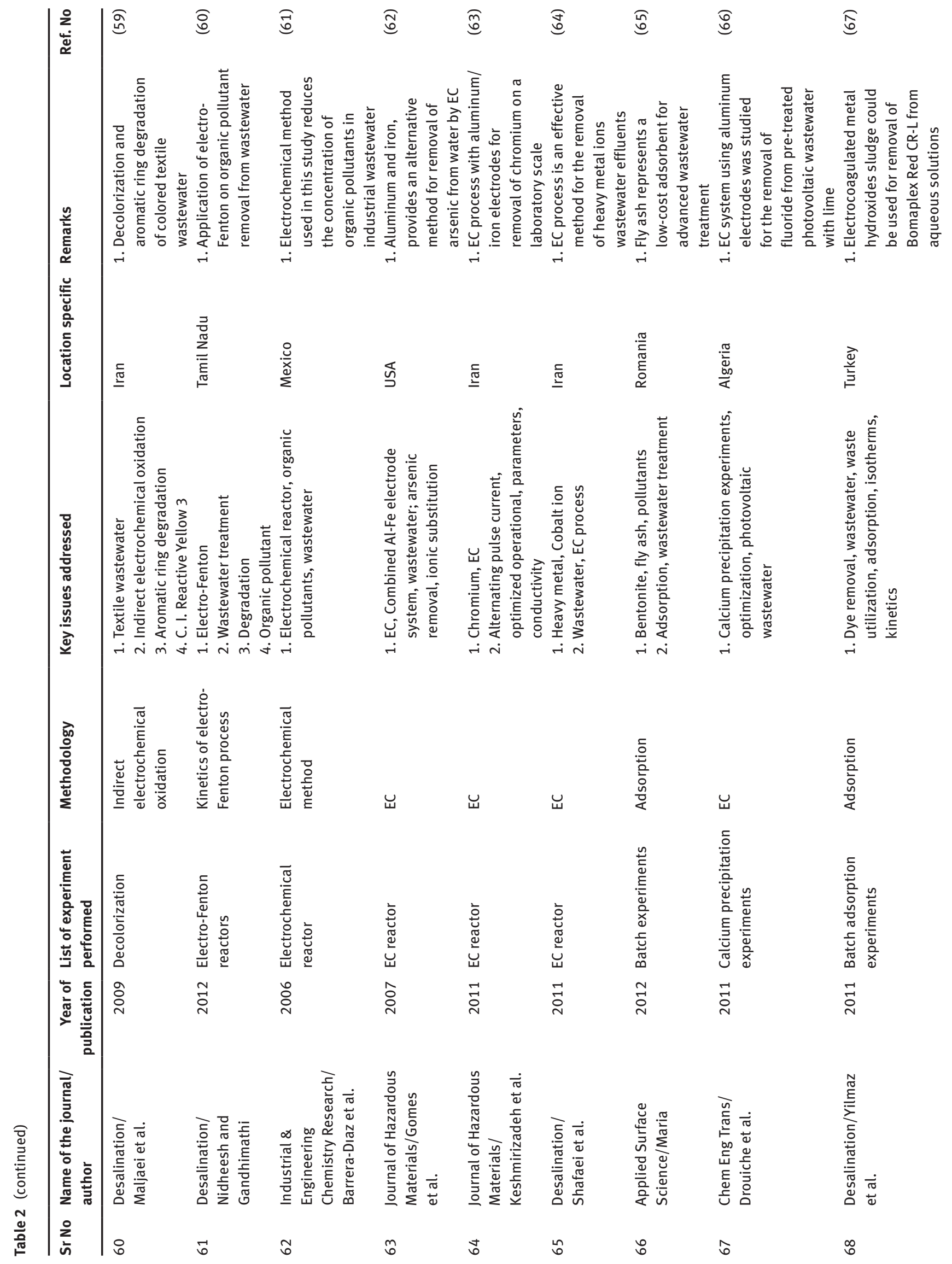




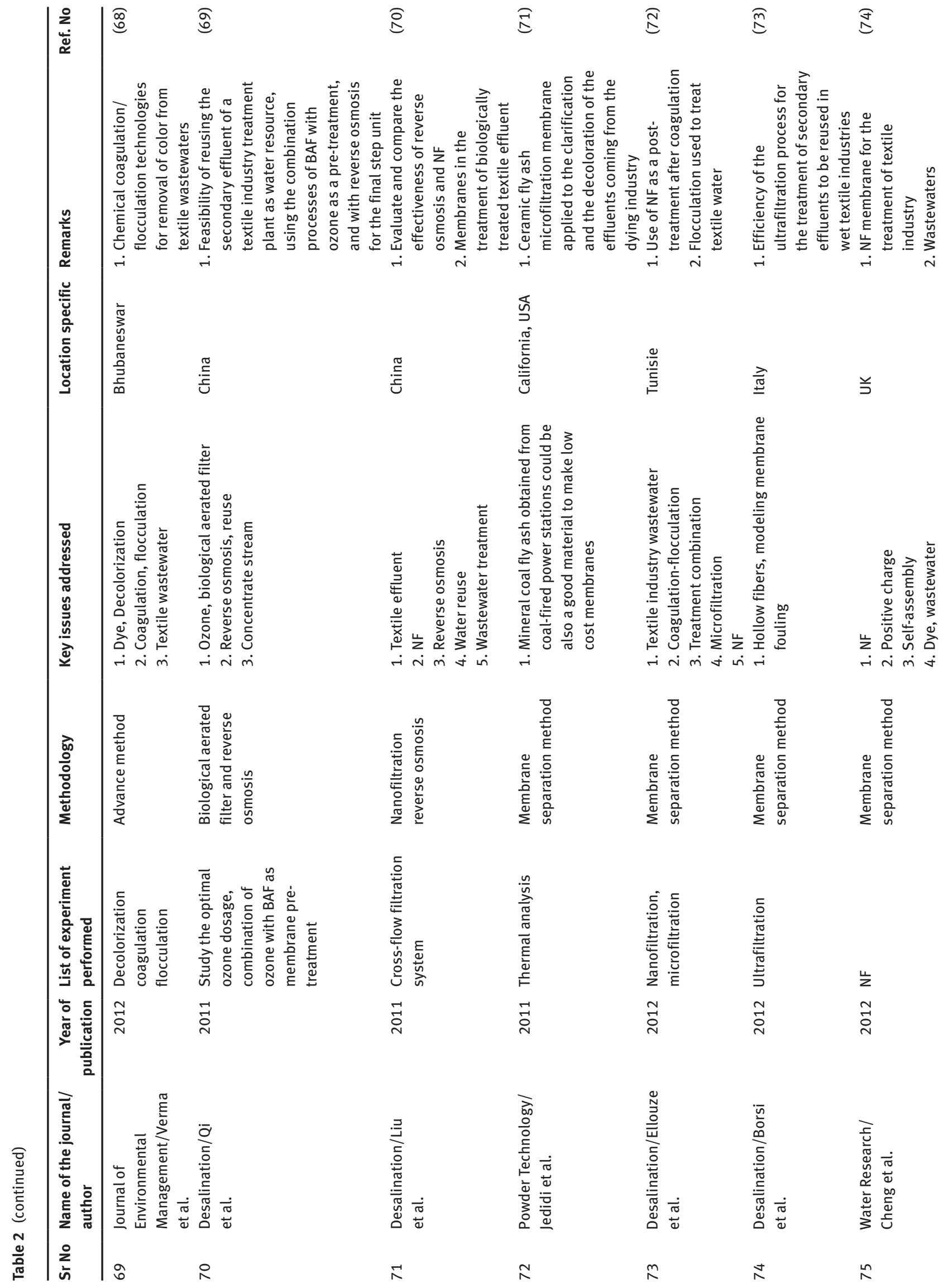




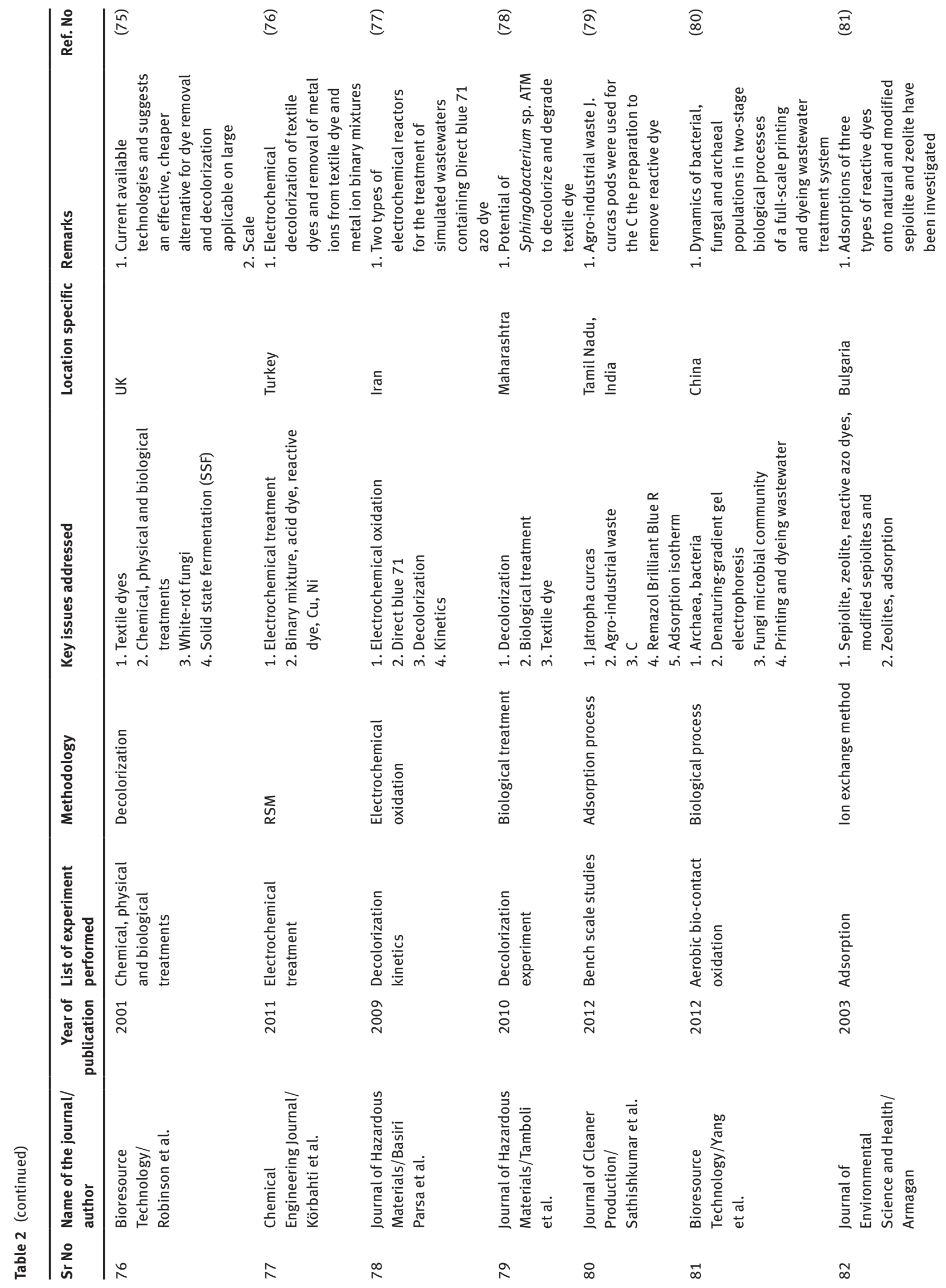




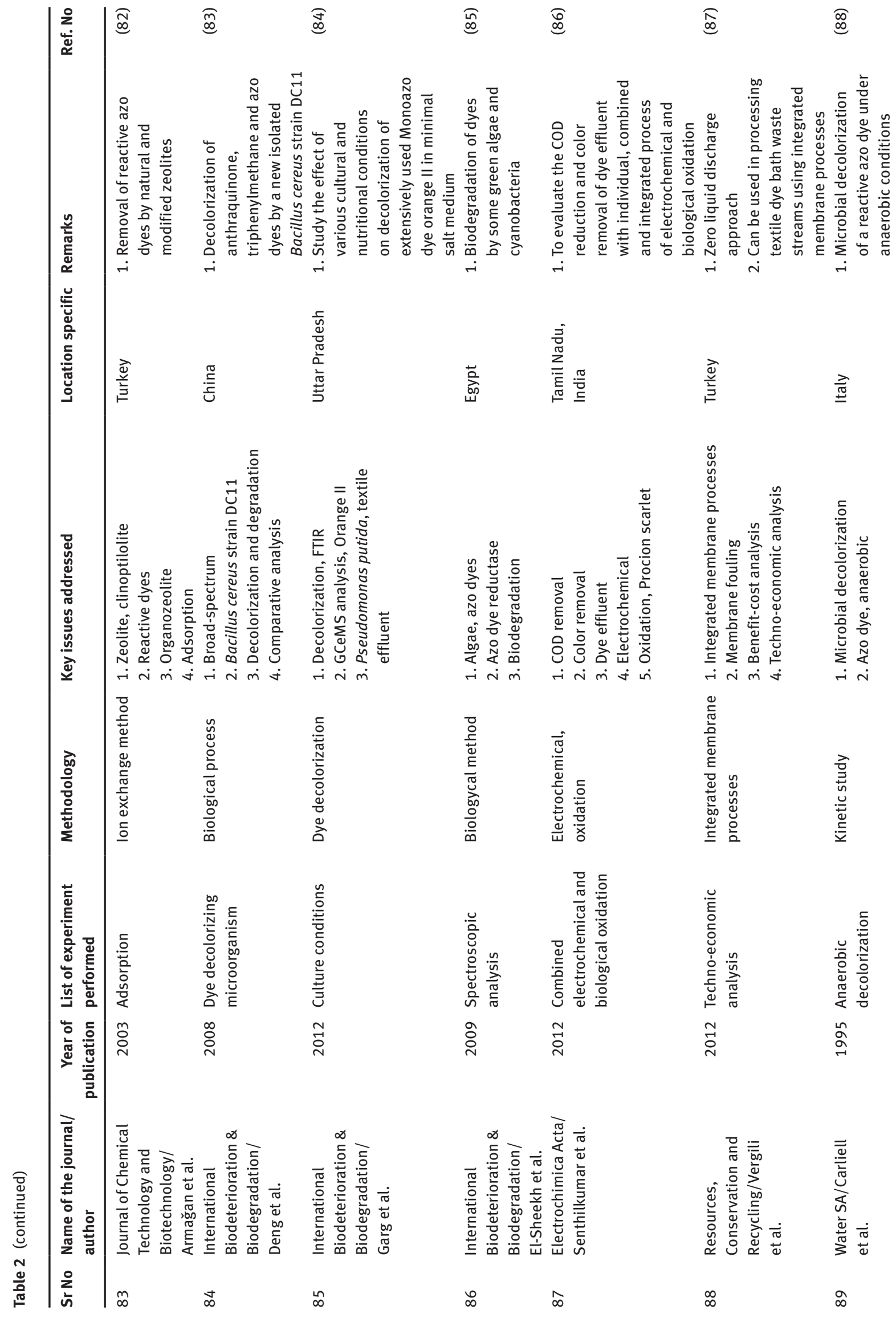




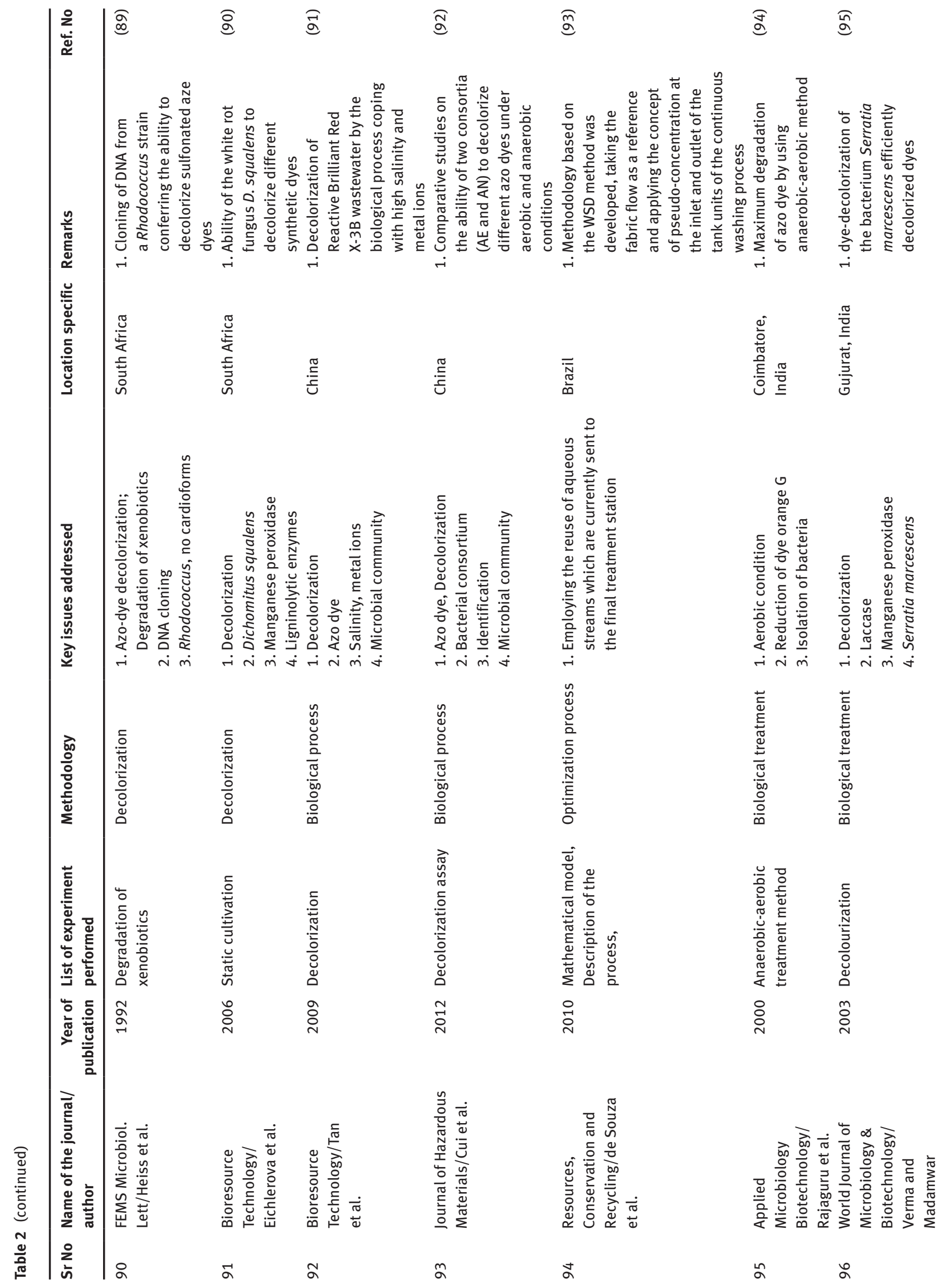




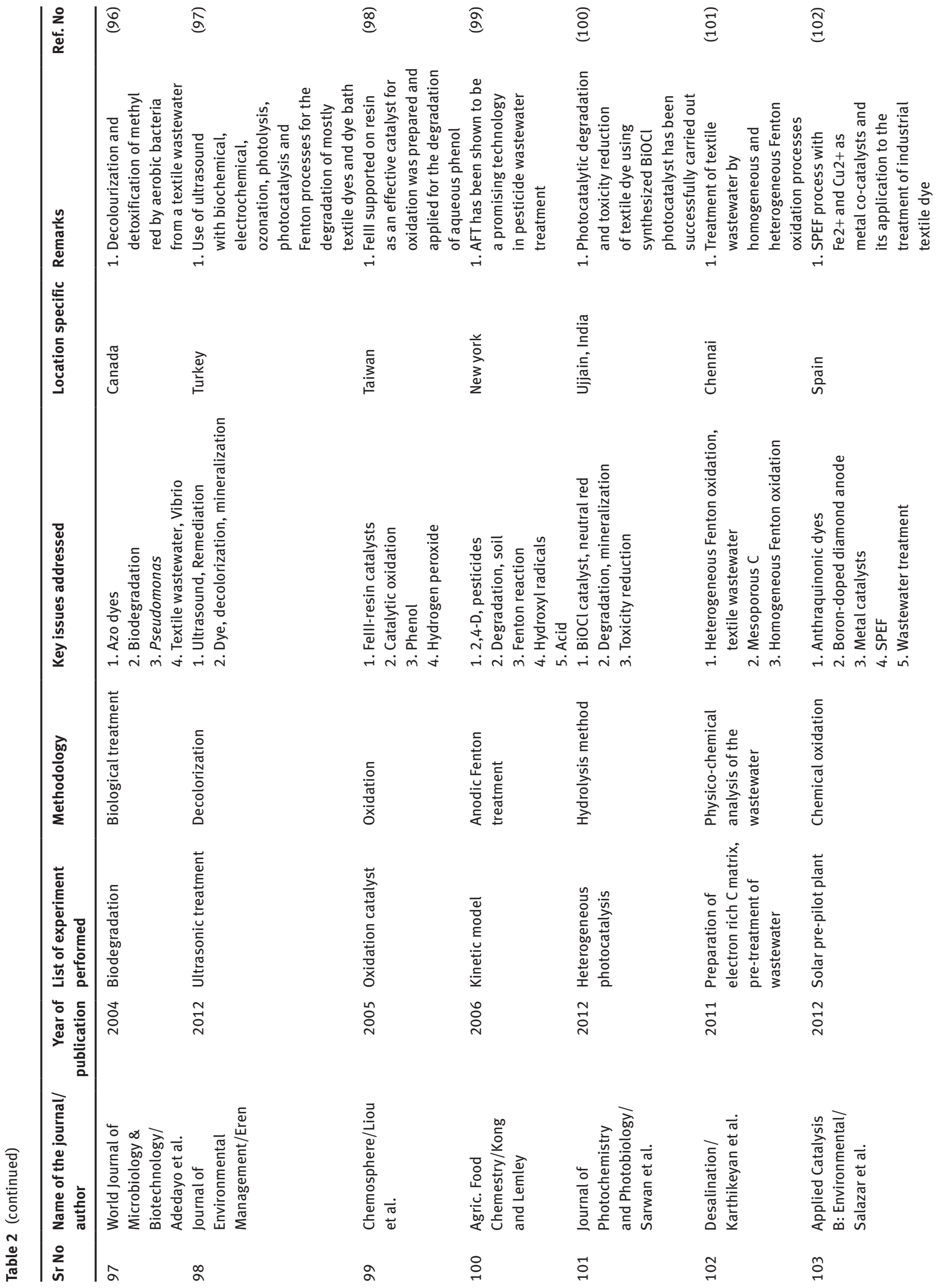




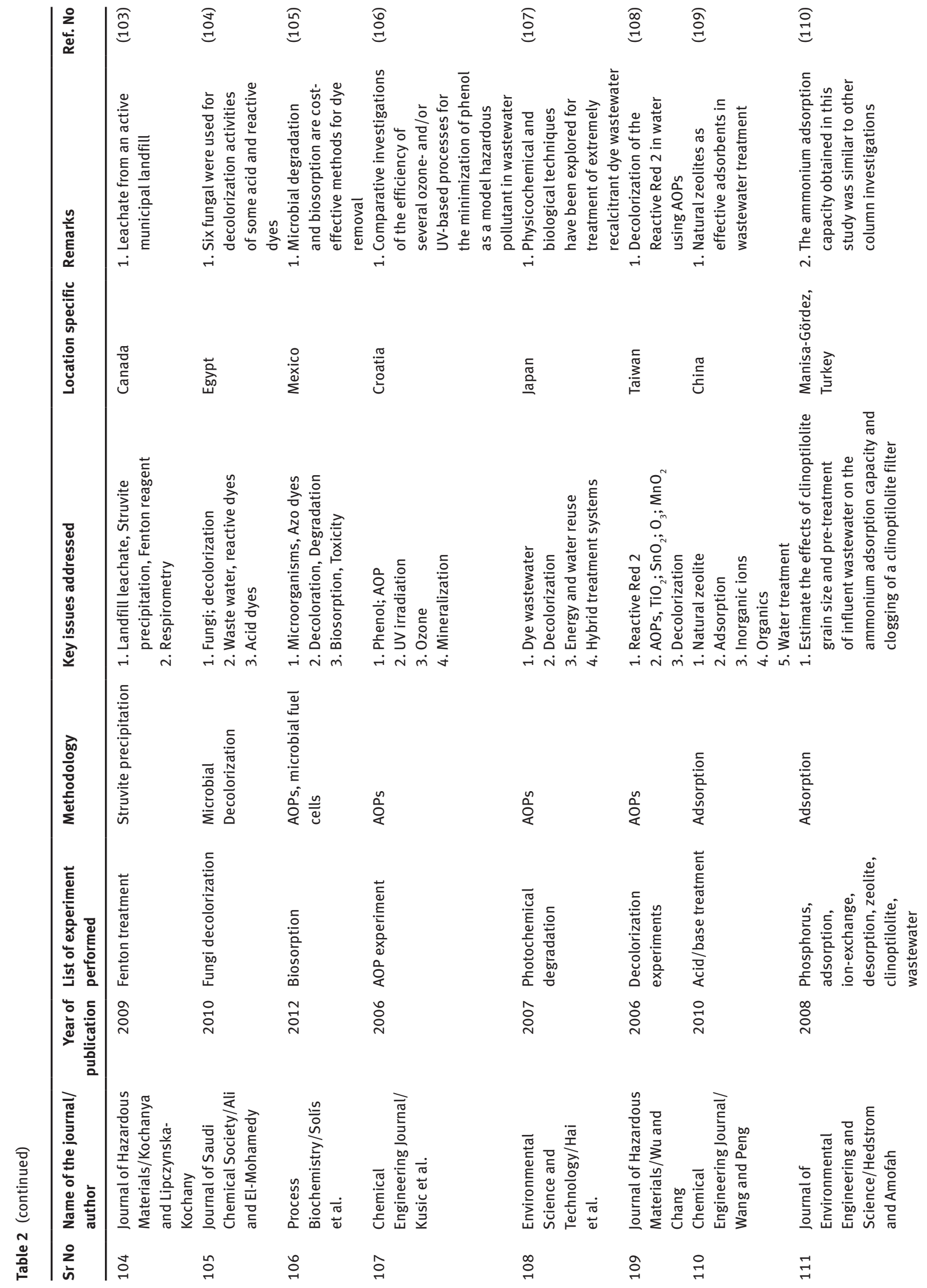




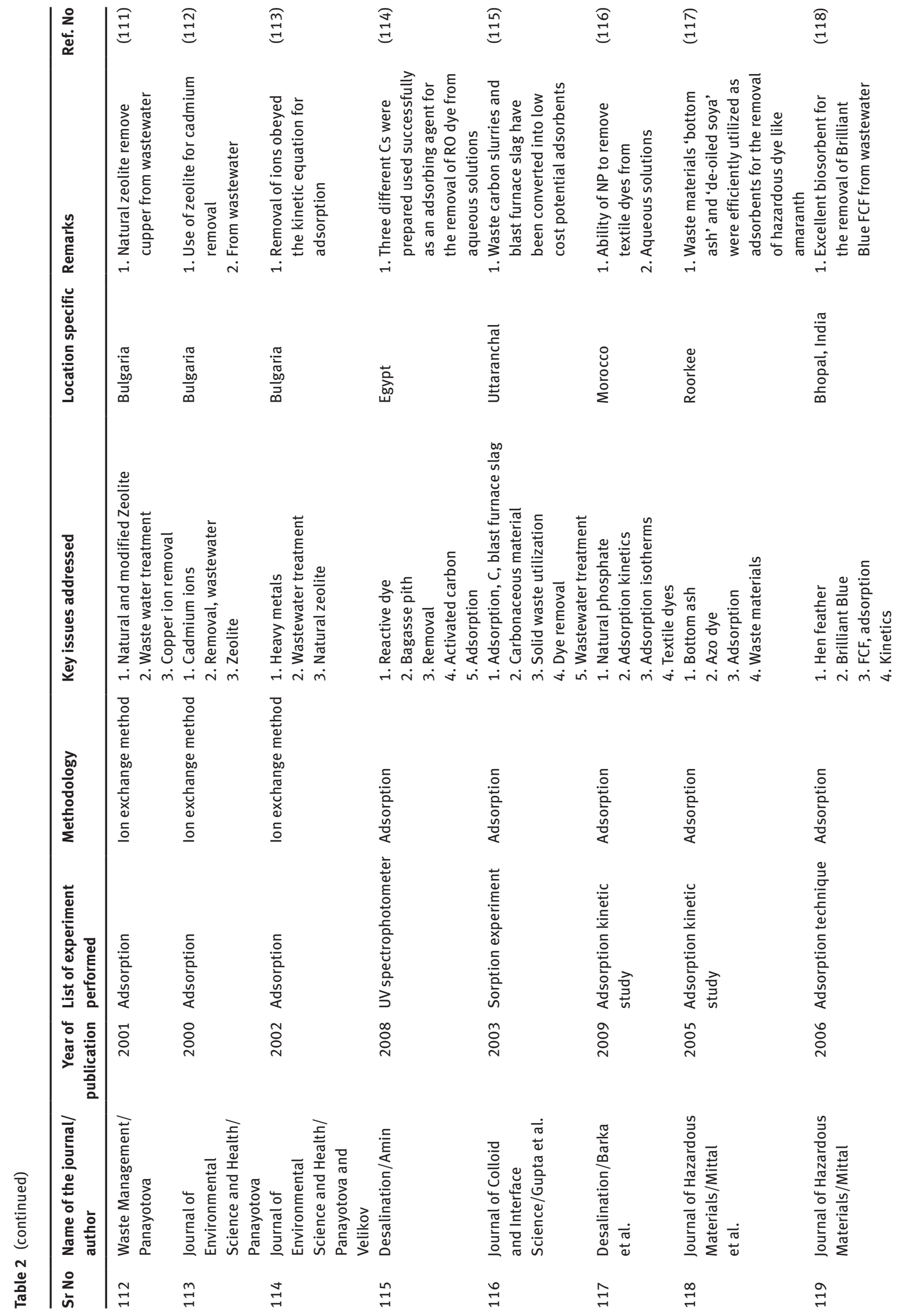




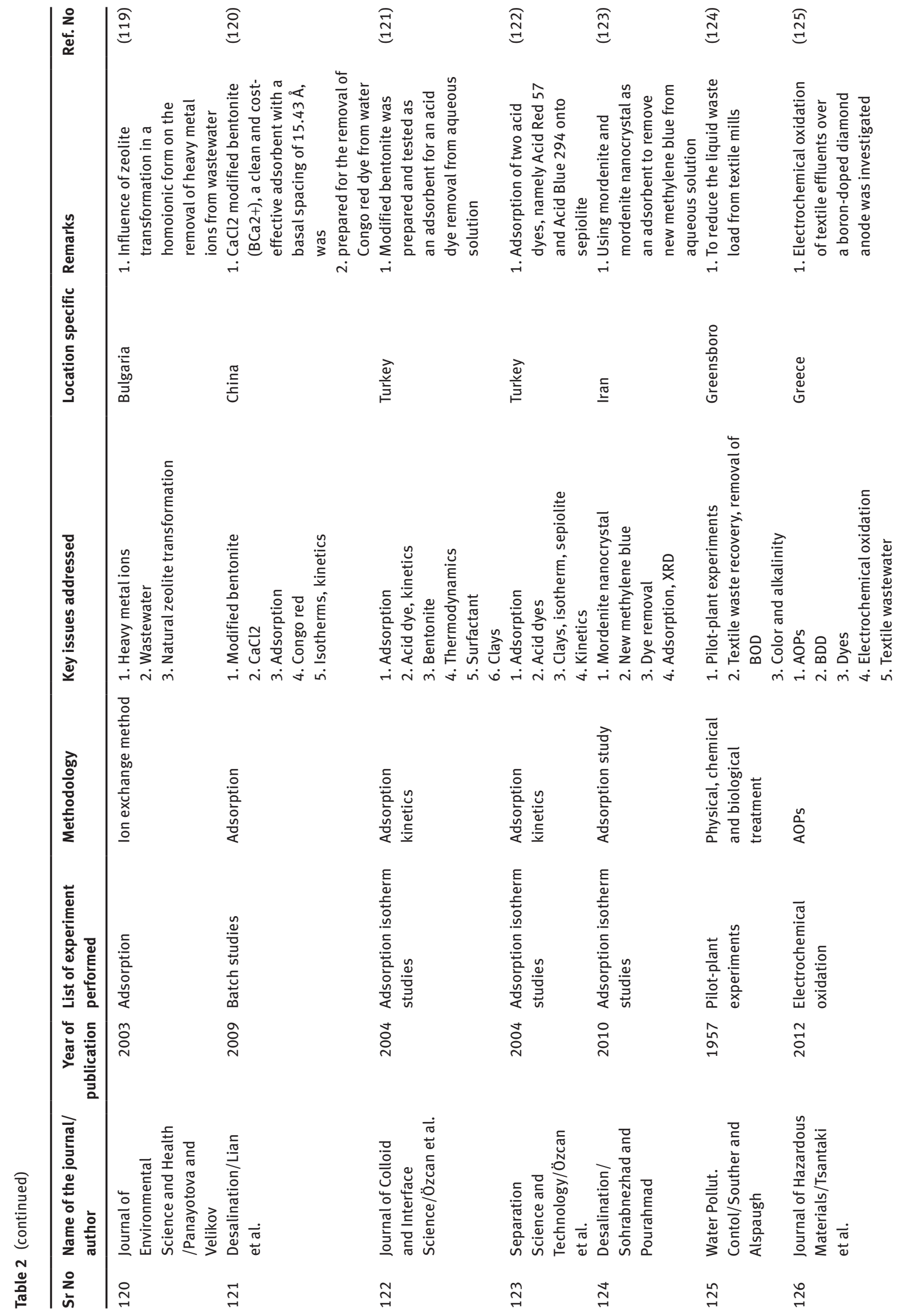




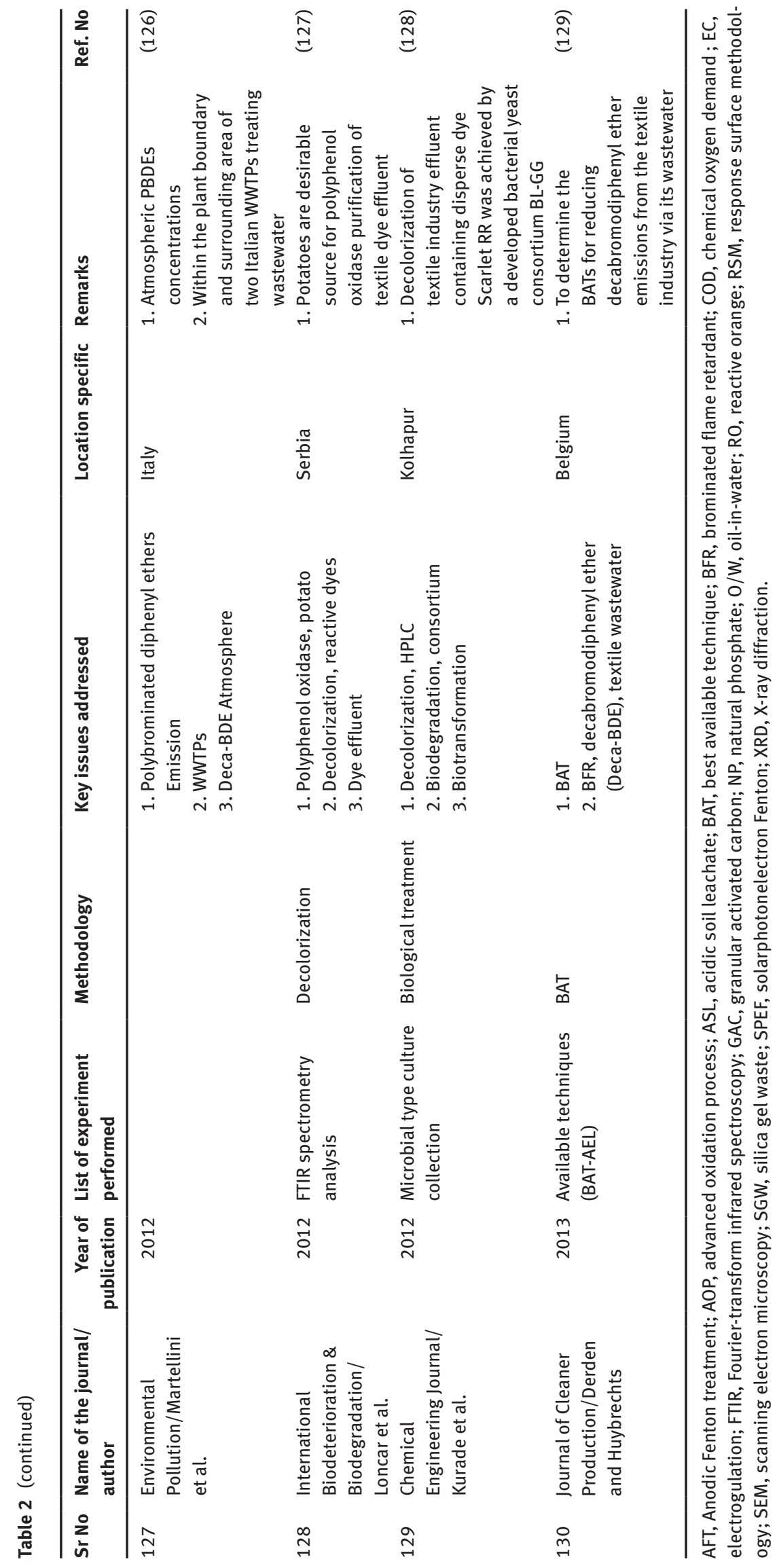


Again, Malik (151) studied the adsorption capacity of activated $\mathrm{C}$ used for the removal of acidic dyes from aqueous solutions, and the activated $\mathrm{C}$ was prepared from low cost mahogany sawdust and rice husk, respectively. The author also observed that the acidic dye not was only available in textile wastewater but also from other waste waters such as paper, soap, cosmetics, wax, and polishes, etc. Finally, the author concluded that sawdust $\mathrm{C}$ had better adsorption capacity as compared with rice husk and mentioned that the adsorption capacity was mainly dependent on contact time, adsorbent dose and $\mathrm{pH}$ value of the wastewater, respectively (152). However, Chuah et al. (153) studied only rice husk instead of using both sawdust and rice husk for the preparation of activated $\mathrm{C}$ to remove the acidic dye. They used rice husks for the removal of heavy metal as well as dye removal as a low cost biosorbent and also predicted that the sorption capacities could be achieved only in specific conditions, i.e. treatment processes, metal concentration, temperature, contact time as well as $\mathrm{pH}$ value. Similarly, Wong et al. (154) considered modified rice husk (agriculture wastes or by-products) by different carboxylic acids to improve the binding capacity for removal of $\mathrm{Cu}$ and $\mathrm{Pb}$ (hazardous materials) from aqueous solution.

Another group of researchers used fly ash, an industrial waste, obtained from thermal power plants for the adsorption of reactive dyes from aqueous solutions [Dizge et al. (146)]. The fly ash has been used a potential adsorbent for removal of reactive commercial dyes, i.e. Remazol Brillant Blue, Remazol Red 133 and Rifacion Yellow HED from aqueous solutions. Similarly, Kara et al. (155) studied both the adsorbent dosage and particle size of the three reactive dyes, i.e. Remazol Brillant Blue, Remazol Red 133 and Rifacion Yellow HED from aqueous solutions using fly ash as an adsorbent under equilibrium conditions. They also recommended that with the increase in adsorbent dose and decrease in particle size the adsorption capacity of the reactive dyes also increased. Again, Sun et al. (147) reported on both reactive dyes (i.e. Reactive Red 23 and Reactive Blue 171) and acidic dyes. Acid Black 1 (156) and Acid Blue 193 from aqueous solutions using fly ash as an adsorbent by taking into consideration the dye concentration, adsorption temperature, time and $\mathrm{pH}$ value of the solution, respectively. They concluded that for reactive dyes removal the $\mathrm{pH}$ value of the solution should be $7.5-8.5$ and for acidic dyes removal, the $\mathrm{pH}$ should be 5-6, respectively, with an optimal temperature of $293 \mathrm{~K}$ for 60 min reaction time.

In another study, Lin et al. (157) reported that removal of basic dye from an aqueous solution using fly ash particulates as an adsorbent. In this research work, they treated the industrial waste fly ash with sulfuric acid (as a low-cost adsorbent) for the removal of a primary dye (methylene blue) from the aqueous solution. They also studied the adsorption behavior by using a pseudosecond-order model and critically examined the kinetic study, where a positive value of the enthalpy indicates an endothermic nature, and the low cost of activation energy of adsorption (E) suggests the adsorption process might be mainly physical. Ferrero (158) discussed hazelnut shells and sawdust for removal of methylene blue, basic dye and Acid Blue 25 from aqueous solutions and conducted several sets of experiments about the adsorption capacity of the shells and sawdust. Through the experimental run, the author concluded that hazelnut shells were better adsorbents as compared with the sawdust for removal of methylene blue from the aqueous solution. Ong et al. (159) conducted several sets of experiments for the removal of either anionic or cationic dye because of most of the wastewater consisted of a mixture of both basic and acidic dyes. Hence, to remove both the types of dye, the authors first chemically modified the rice hull and then used it as an adsorbent for the removal of acidic dyes. The detailed analysis of the above technique is summarized along with crucial issues raised during the review of the published research as mentioned in Table 3.

\section{Study on the effective utilization of textile sludge for the preparation of a concrete structure in the replacement of cement}

The Indian textile industry is one of the oldest platforms for the development of dyes on natural and synthetic fabrics. There are huge quantities and varieties of dyes and other chemicals coming out in the water and this creates a significant problem for society as well as the environment. This wastewater ultimately becomes mixed with river water or mixed with soil water, which eventually causes major problems in society both in liquid and chemically reactions with the environment. Hence, nowadays the significant challenges are the utilization of textile wastewater with either the wastewater being treated for reuse in textile industry through different treatment techniques or the huge cost involved in the treatment of the wastewater. Hence, low cost natural treatments such as CKD, activated C, coal, fly ash and sawdust, etc. may be used as absorbents. At the end of treatment, on the one hand, the waste water is converted to ordinary water for reuse application in the textile industry, simultaneously huge quantities of 


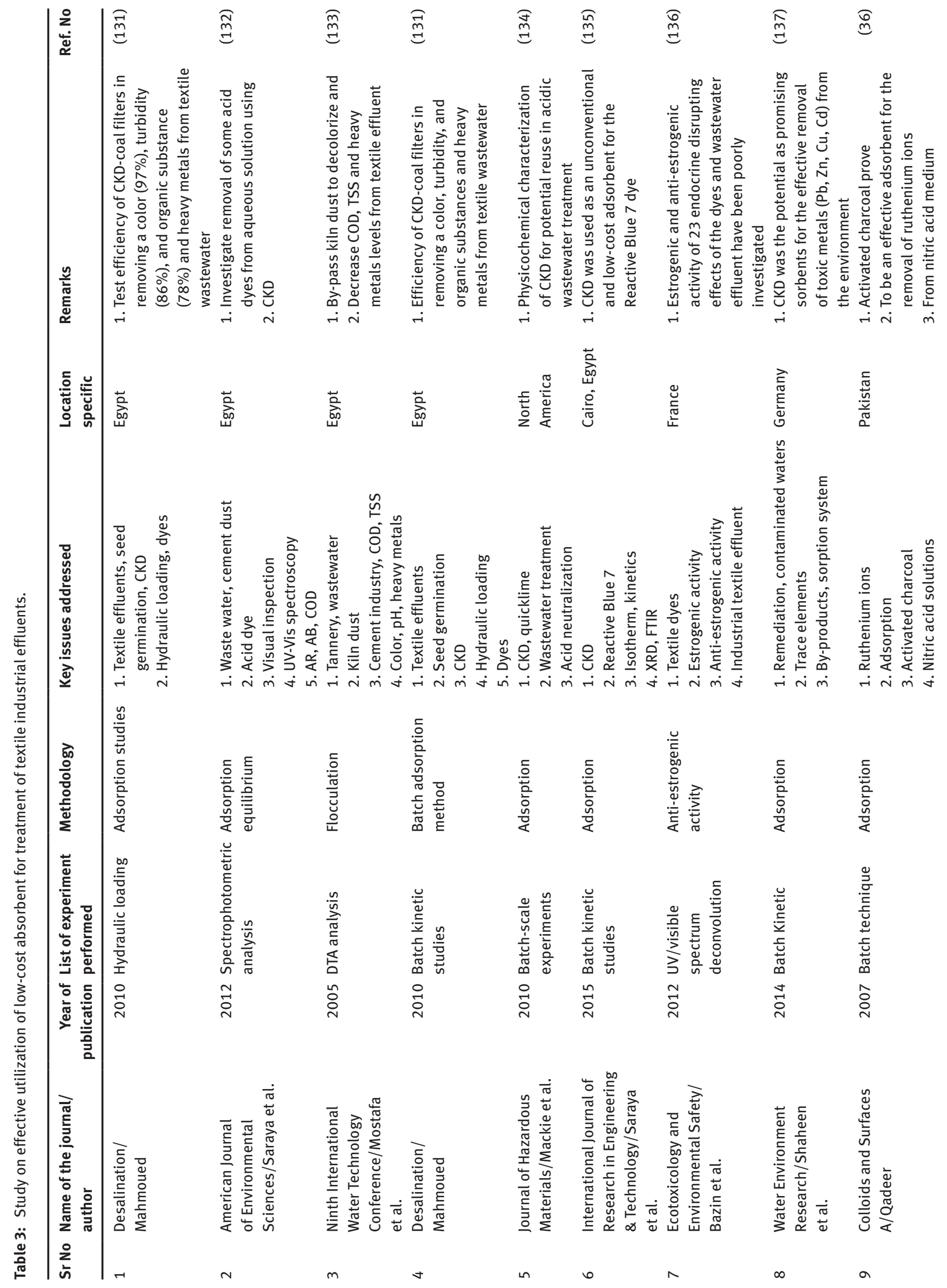




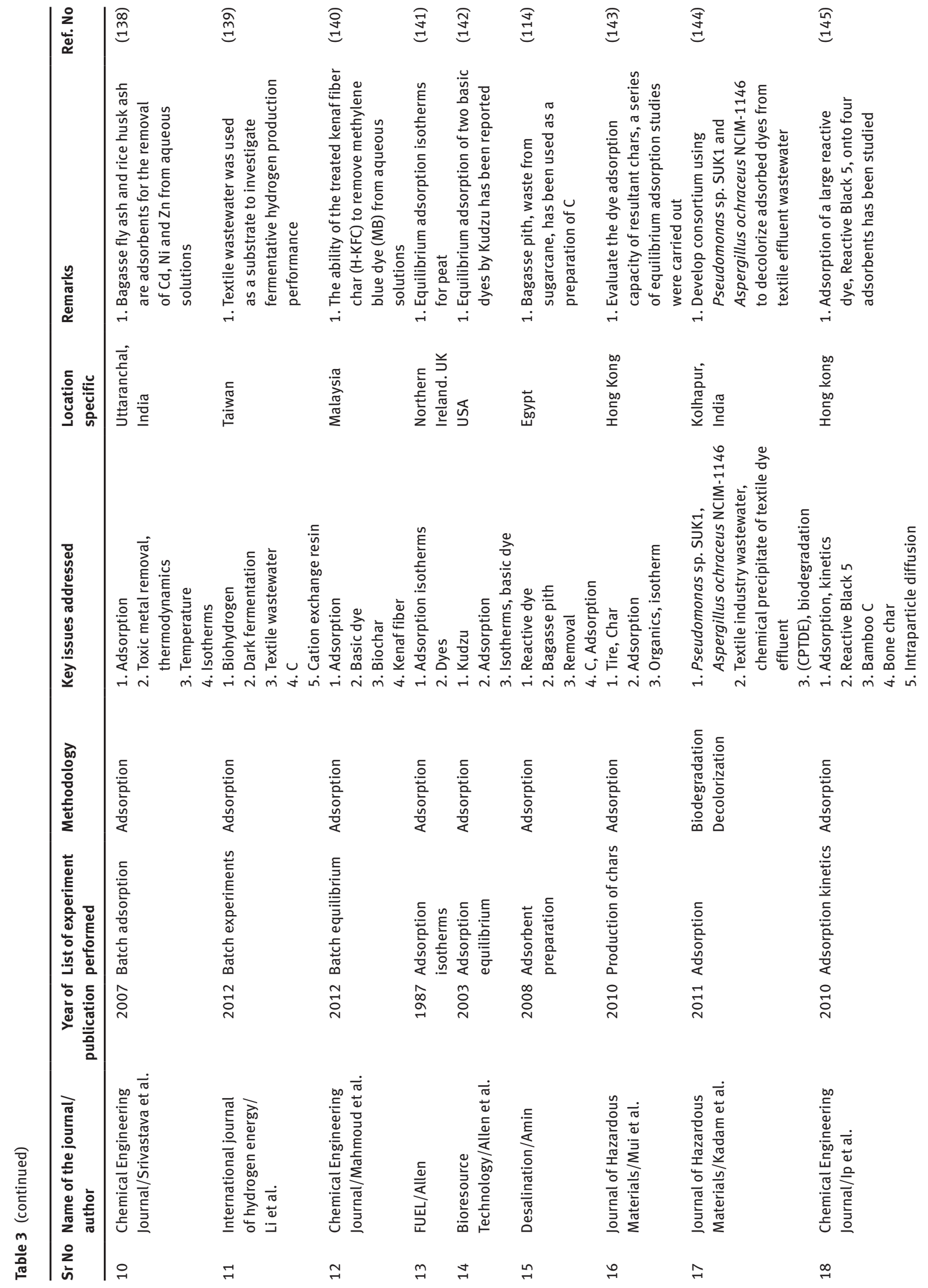




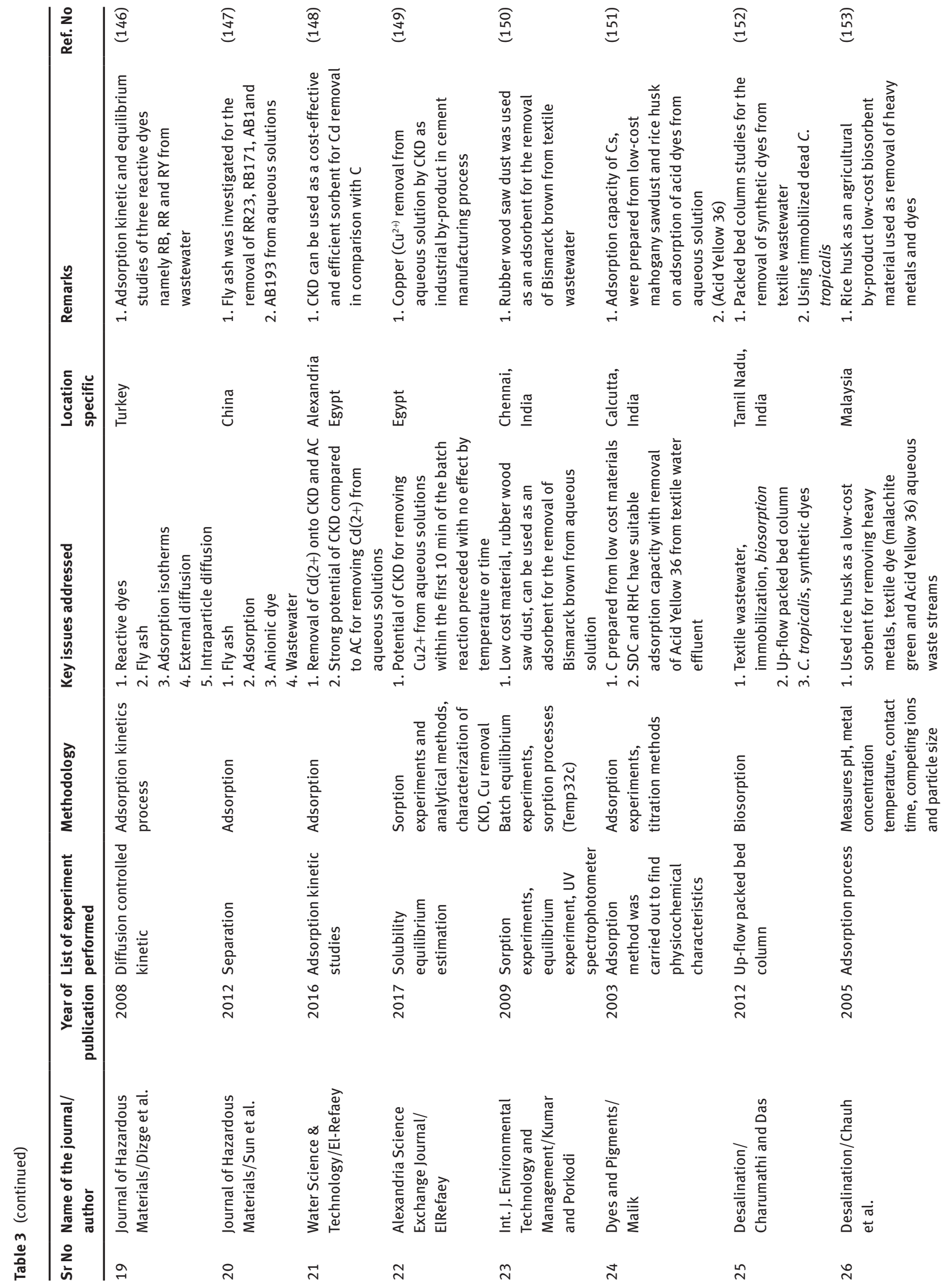




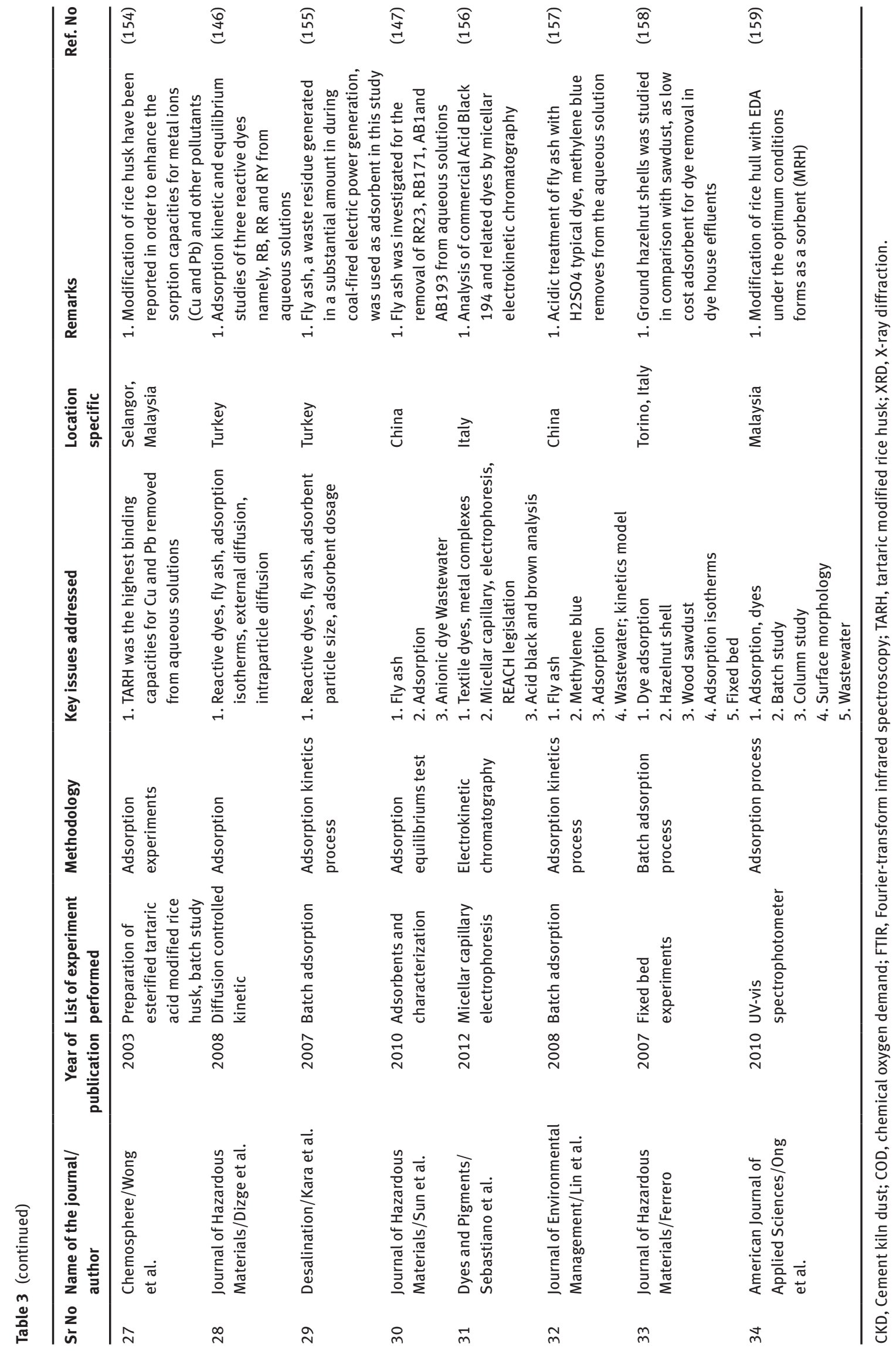


textile sludge is also produced as a byproduct of the textile industry. In India, nearly 70 to 80 million tonnes of textile sludge are produced as a byproduct every day. Therefore, the disposal of sludge is also a challenging job nowadays in the textile industry, because these waste sludges cause pollution the control board also bans environmental pollution as well as dumping of sludge. Therefore, most of the researchers have developed an alternative use of textile sludge in other sections like the replacement of certain types of cement for construction of the concrete structures, bricks and retaining walls, etc.

Lekshmi and Sasidharan (160) prepared four different concrete cubes with varying percentages of the weight of textile sludge, water and cement ratio and determined the strength, splitting strength and elasticity modulus of the concrete mixed specimens. They observed that for $10 \%$ of cement replacement of textile sludge at $0.4 \%$ watercement ratio the compressive strength was found to be 29.33 MPa, which satisfied the compressive strength of the paver block as a standard. Therefore, ultimately the cost of the concrete structure can be reduced through the partial replacement of cement. Similarly, Kulkarni et al. (161) studied the feasibility of textile mill sludge as a fine aggregate in M:20 grade of concrete. They observed that in a conventional concrete mix structure the density, workability and reduction in compressive strength obtained with the replacement of fine aggregate by textile mill sludge is beyond $32 \%$. Therefore, to enhance the compressive strength of the concrete structure, industrial waste such as fly ash was added in the replacement of cement along with $32 \mathrm{wt} . \%$ of textile mills' sludge. They noticed that the compressive strength of the prepared concrete structure was slightly decreased with the addition of fly ash. Balasubramanian et al. (162) and Rahman et al. (163) studied the possible use of textile sludge in structural materials and to non-structural building materials due the combination ratio of cement and textile sludge failed to achieve the standard of the structural applications. Therefore, they studied non-structural applications for feasibility analysis as per ASTM standards for nonstructural materials. Similarly, another group of researchers [Sudheesh et al. (164)] proposed the use of textile sludge for the replacement of cement and fine aggregate to fabricate paver blocks; for the addition of textile sludge for the replacement of cement the compressive strength showed inferior properties. Therefore, they modified the proportion ratio by the addition of another waste, i.e. quarry dust with textile sludge in place of the cement. The compressive strength of the new combination of the composites has shown improved properties by replacing a portion of the cement along with quarry dust and textile dust.
Raghunathan et al. (165) developed a new combination of composites by using existing non-degradable and hazardous waste material mixed with Portland cement replacing the sand and related aggregates, due to nonavailability of silica sand. The proposed composites have a good quality of being reasonably low cost in making the composite and could be used as an unconventional building material, i.e. synthetic sludge aggregate. Shivanath et al. (166) studied the efficient utilization of textile effluent treatment plant (ETP) sludge for the replacement of cement in concrete structures (M20 standard). The sludge was collected from the lime treatment of automobile, engineering and lead battery industries effluents. They prepared the blocks of the mixture of cement and three different weight percentages of sludges, i.e. $5 \mathrm{wt} . \%$, $10 \mathrm{wt} . \%$ and $15 \mathrm{wt} . \%$, respectively. The highest compressive strength was obtained in 5 wt.\% sludge mixed with cement after 28 days curing. However, Weng et al. (167) discussed only textile industry sludge for the manufacturing of low-grade bricks. They mainly concentrated on the percentage of sludge and the firing temperature to improve the quality of the bricks and studied different weight percentages of the sludge. Finally, they finished with 20 wt.\% sludge incorporated into the brick manufacturing and tested the strength up to $860-960^{\circ} \mathrm{C}$. However, on further increase in the percentage of sludge the strength, water absorption capacity and brick shrinkage was reduced. Sayyad et al. (168) developed new materials by combining two different wastes collected from two various sectors such as textile waste (sludge) and plaster of Paris waste, respectively, to improve the sustainability of the material. Again, another group of authors studied the use of textile sludge for the replacement of cement for the manufacturing of M30 grade rubber mold paver blocks (RMTBs), where the sludge weight percentage varied from $0 \mathrm{wt.} \%$ to $40 \mathrm{wt} . \%$ at an interval of $5 \mathrm{wt} . \%$, respectively. The effective weight percentage of manufacturing the paver block was $20 \mathrm{wt} . \%$ sludge beyond which the properties were slowly decreased [Patel et al. (169)]. Again, Patel and Pandey (170) collected sludge from cotton dyeing and printing operations' hazardous wastes after treatment for reuse in construction materials. The chemical sludge was used along with cement by varying the percentage of sludge from $30 \mathrm{wt} . \%$ to $70 \mathrm{wt} . \%$, respectively (171). The prepared brick was satisfied the BIS standards for the classes of $\mathrm{C}$ to $\mathrm{K}$ up to the strength of $25 \mathrm{~N} / \mathrm{mm}^{2}$.

Sahu et al. (172) studied sewage sludge pellets for the replacement of sand mixed with cement in the manufacturing of pavements. In this study, the authors took all the three sludges such as dried sludge, sludge pellets and sludge ash, respectively, for preparation of building 
materials. They also concluded that with $20 \mathrm{wt} . \%$, sewage sludge may be used for the manufacturing of soft mud bricks, 30 wt.\% sludge may be replaced with mortar from water and sewage treatment plant for the preparation of bricks. João Marciano (173) reported on waste textile trimming fibers mixed with resin/sand aggregate for the development of polymer concrete. They successfully studied the flexural as well as the compressive strength of the polymer concrete at room temperature. However, the strength performance was not effective against the function of textile trimmed fibers. Kaur et al. (174) discussed the efficient utilization of textile mill sludge obtained from ETPs and observed that the increased textile sludge causes a reduction in strength of the concrete. After continuous analysis of the study the authors introduced a certain quantity of plasticizer along with textile mill sludge in concrete and reported that the compressive strength of the concrete was $23.55 \mathrm{~N} / \mathrm{mm}^{2}$ for $\mathrm{M} 20$ grade concrete.

\section{Study on the direct reusing of textile wastewater without further secondary treatment}

In India a large number of textile industries where dyeing and finishing processes are the principal activity they require a significant quantity of pure and excellent quality of water. As water is also one significant constituent nowadays in the textile industry, simultaneously, the wastewater also creates a significant problem for society as well as the environment. The waste may be liquid wastes, solid waste or contaminants, which directly affect the river water and soil water also. Therefore, to reduce these textile wastes, there is currently a lot of research in this area. The conventional method is processing the wastewater using different treatment methods and reusing it in the textile industry, where costs, as well as time, are the significant parameters. Shaid et al. (175) proposed a cost-effective technique for the reuse of textile wastewater without treatment, which reduces the consumption rate of the fresh water as well as the treatment time. They studied nearly six different types of rinsing wastewater and used the rinsing wastewater to scour bleach knitted cotton fabric. Finally, they concluded that the weight loss of the scoured bleached sample was nearly $6.53 \%$ in a fresh water medium and $6.65 \%$ in a wastewater medium after dyeing the bleached samples. The reflectance of whiteness was found to be $76.68 \%$ and $77.92 \%$, respectively, for bleached wastewater and fresh water samples.
Again, Erdumlu et al. (176) proposed an efficient technique for the reuse of textile wastewater after primary treatment instead of going through all of the three to four treatment processes, the basic treatments being filtering, ion exchange, airing and $\mathrm{pH}$ regulating, respectively. In their research they defined that the effluent water being passed through microfilters, which is a cost-effective and straightforward methodology. The reuse of the water obtained through microfilters is a type of membrane separation technique, which removes suspended solids, COD and color, respectively. Whereas, the hardness and conductivity of the effluent can be changed by the use of natural minerals like zeolite instead of using an advanced membrane separation technique. However, Roohi et al. (177) proposed an alternative method for the use of textile wastewater for irrigation purposes instead of direct use in the textile processing industry and reported the nature/ strength of soil properties by the use of untreated waste water. The reuse of wastewater was applied to different soils for irrigation purposes but repeated use of wastewater may affect the soil properties.

\section{Study on the cost-benefit analysis of textile wastewater used in the textile industry}

Dogan et al. (178) studied a denim textile mill's wastewater as per the European Union's integrated pollution prevention and control directive for processing and implemented different wastewater treatment (end-of pipe and several other water recovery techniques) techniques to observed the best available techniques (BATs) from the above alternatives. Therefore, on the basis of economic viability of the availability techniques most of the textile mills are ready to invest at a high cost initially because for the long run the efficiency of water recovery may be increased. Chougule and Sonaje (179) primarily proposed the cost-benefit analysis of the wastewater recycling only in wet processing and also suggested that almost all the industries must follow the water management techniques for alternative sources of pure water starting from wet processing to finishing product analysis. In the end, as reported using ISO-105 and AATCC methods the washing and rubbing fatness of the fabric was more satisfactory. Teal (180) conducted sensitivity analysis for all the treatment processes available to-date and developed a cost-effective technique based on the present lists of treatment processes by avoiding pretreatment processes of each in every case. The author mainly 
focused on the decreased use of dye and fabric as far as benefits were considered and also suggested a significant justification for the reduction of chemicals during processing, labor, variable overheads as well as fixed overheads. El-Dein et al. (181) discussed the cost analysis of the textile dyes processing and combined $\mathrm{H}_{2} \mathrm{O}_{2} / \mathrm{UV}$, and the biological treatment process (9) at higher concentration of reactive textile dye uses. They suggested that $\mathrm{H}_{2} \mathrm{O}_{2}$ has no absorption capacity but with improved UV technology it may improve the efficiency and also the biological treatment stage can reduce energy cost to get a higher degree of mineralization (182). Again, Libra and Sosath (183) suggested the overall cost-effectiveness must be a combination of the capital as well as the operating cost. They reported that for ozone treatment the investment cost was much higher whereas, by combining the ozone and biological treatment process it was less expensive due to a one-stage ozone process instead of two different treatment processes. Similarly, Tsai (184) studied the energy utilization from the biological treatment process as a preliminary analysis in Taiwan. Their main finding was combustible waste produced from agriculture and industry sectors and further reused as an auxiliary fuel. Parveen and Rafique (185) developed an optimal technique without the use of additional chemicals at the time of pre- and post-treatment, and also studied the cost-benefit analysis of the proposed efficient method. They showed that the cost analysis of the aluminum salt and foil separately and reported that as the aluminum foil was a waste material it can be recycled and reused with a low operational cost.

The state of Rajasthan consumes $17 \mathrm{~L}$ of water per meter of fabric production, and in Bhilwara town, the fabric preparation capacity is one million meters per days, which consumes 17 million liters per day water. Similarly, other parts of the state such as Jodhpur, Pali, Barmer (Balotra), and Jaipur (Sanganer) also consume equal quantities of water for the preparation of fabrics (186). However, in India, the textile industries alone have a water consumption capacity of $200-250 \mathrm{~m}^{3} /$ tonne cotton cloth, and for the production of man-made fabric, it is $20 \mathrm{~m}^{3} /$ tonne of nylon and polyester produced, whereas it is $150 \mathrm{~m}^{3} /$ tonne for viscose rayon fiber which only produced in Rajasthan state.

In Europe the textile industries' annual fresh water consumption is nearly 600 million- $\mathrm{m}^{3}$ and $90 \%$ of the water is used for textile finishing operations, out of which 108 million tons of wastewater is produced every year but only 36 million tons of chemicals and other auxiliaries are removed from the textile wastewater. However, they have successfully developed an alternative technique for the reuse of textile wastewater mixed with membrane concentrates followed by treatment within the existing biological treatment plant, which can treat nearly $500 \mathrm{~m}^{3}$ /day wastewater and which recovers $374 \mathrm{~m}^{3} /$ day of water (187). The summary of various textile industries which use other alternative techniques for textile wastewater treatments is shown in Table 4.

\section{Future scope of research}

Insufficient research work has been carried out to-date on the direct use of textile wastewater without any further treatment processes and the use of waste sludge for making of building materials such as locking tile and lowgrade bricks by replacing cement. CKD is also one of the industrial wastes obtained from cement industries after cement preparation, and a few researchers have already used this cement kiln waste for the treatment of textile wastewater without any further increase in cost. Similarly, fly ash, quarry dust, plaster of Paris waste, coal, sawdust and activated $\mathrm{C}$, etc. can also be used as low cost natural treatments when used as an absorbent to improve the sustainability of construction material for the preparation of flooring tiles, solid, bricks and pavement blocks, etc. Therefore, more research is required for the detailed analysis of the treatment process without going through any artificial chemical treatment process to obtain a clean and pure environment (Figure 1). Hence, based on the mentioned literature review a number of awareness programs are also needed for the proper utilization of the textile wastes, because textile waste not only contains wastes and chemicals but it also consists of significant amounts of valuable resources that can be used as a raw material for other industrial applications. However, to-date very few textile manufacturing industries have reused wastewater efficiently in the textile industry as well as in agriculture sectors. Therefore, appropriate technology may be developed to improve the wastewater quality or else an alternative arrangement is required to reuse the wastewater and the sludge. Hence, there is huge opportunity for research, in the manufacturing industry, and for society to develop knowledge-based networks to create new guidelines for the production of new products from the resulting waste sludge and wastewater. It also recommends that substantial waste industries such as the textile waste industries should concentrate more on the quality of chemicals used in wet processes as the strength of the chemicals may also affect the reuse quality of wastewater in the industry. In the end, cost-benefit analysis of the all the treatments and the non-treatment procedure is required for the implementation of the optimal methodology in the textile industry 


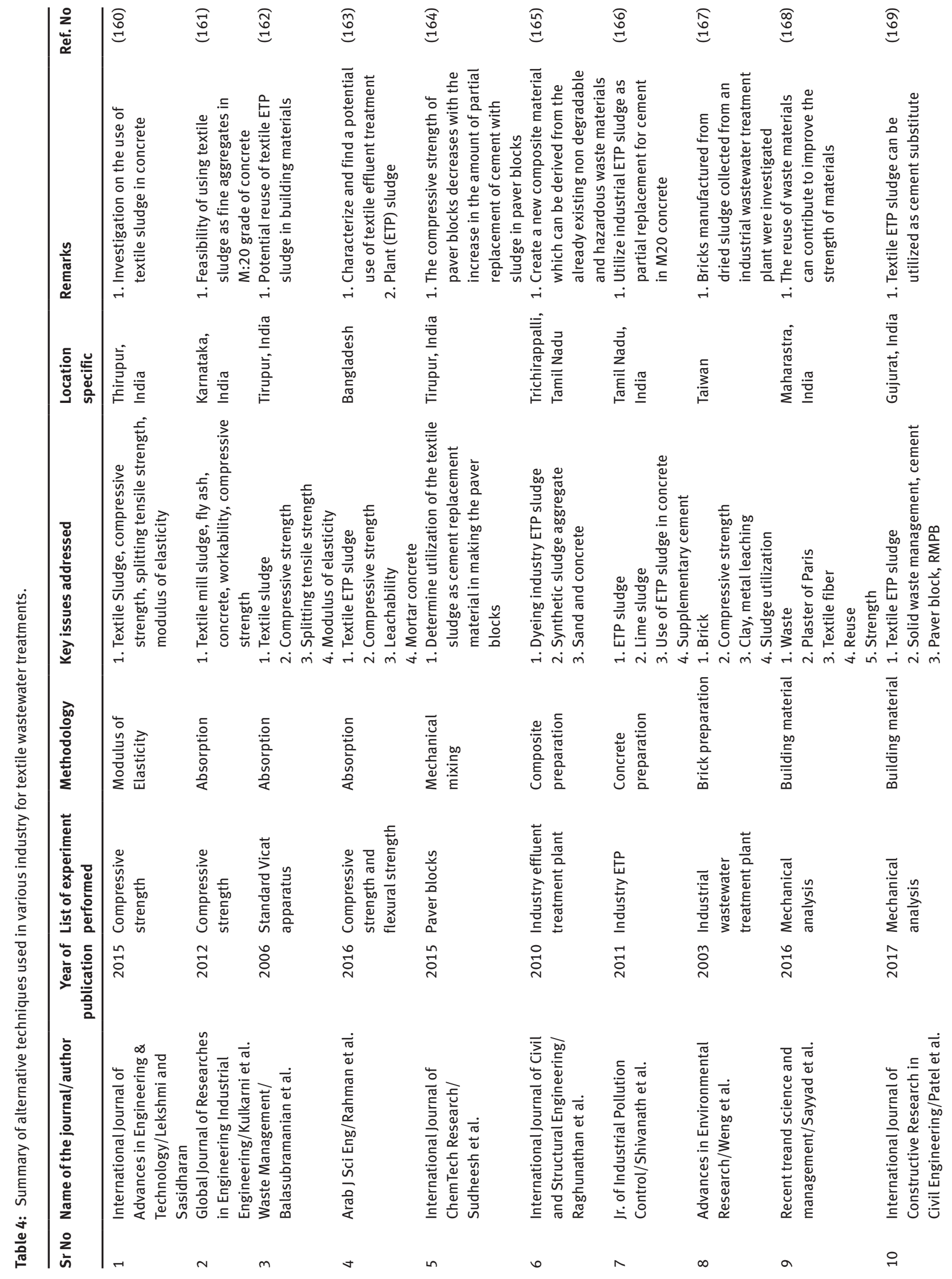




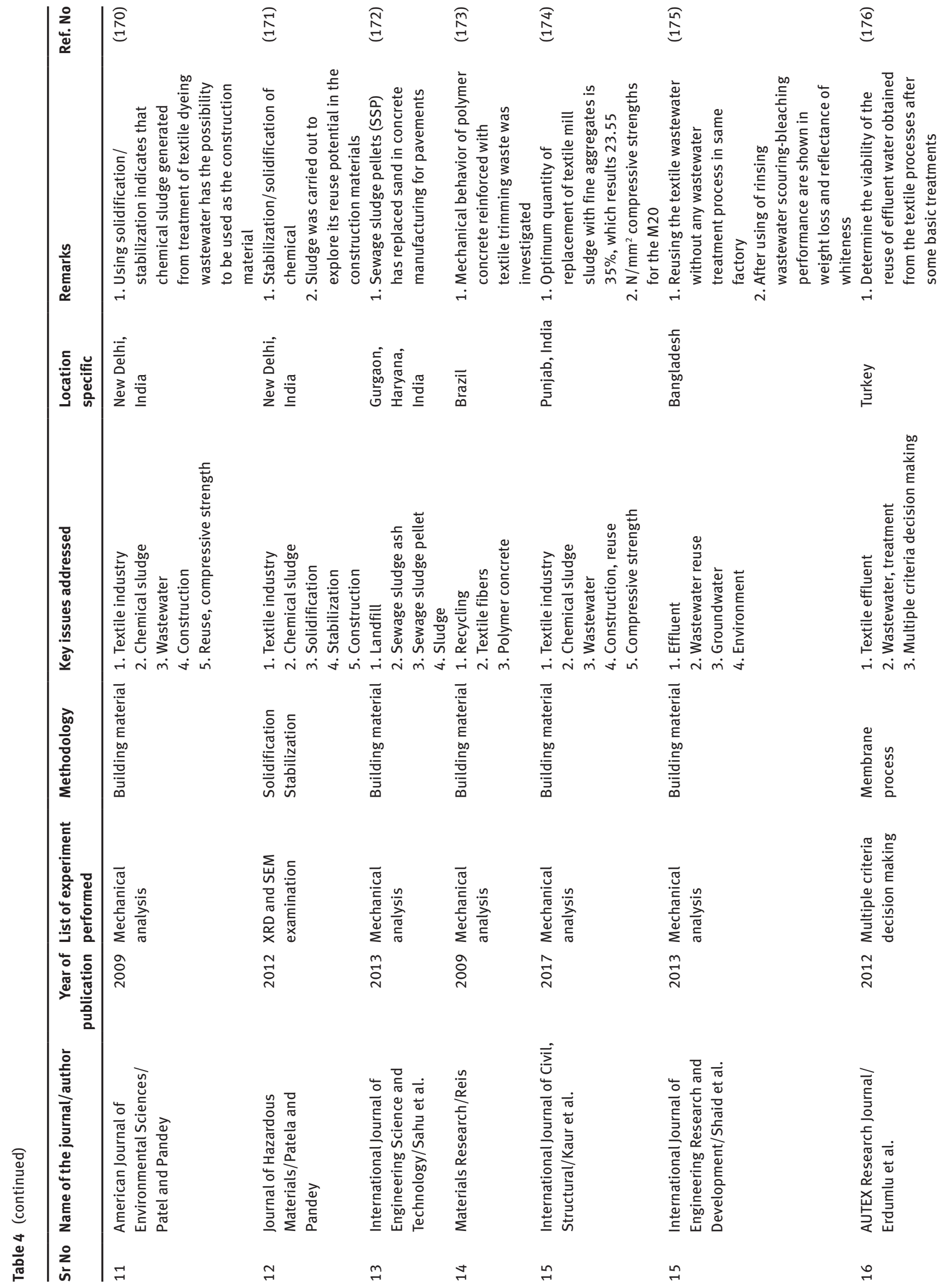




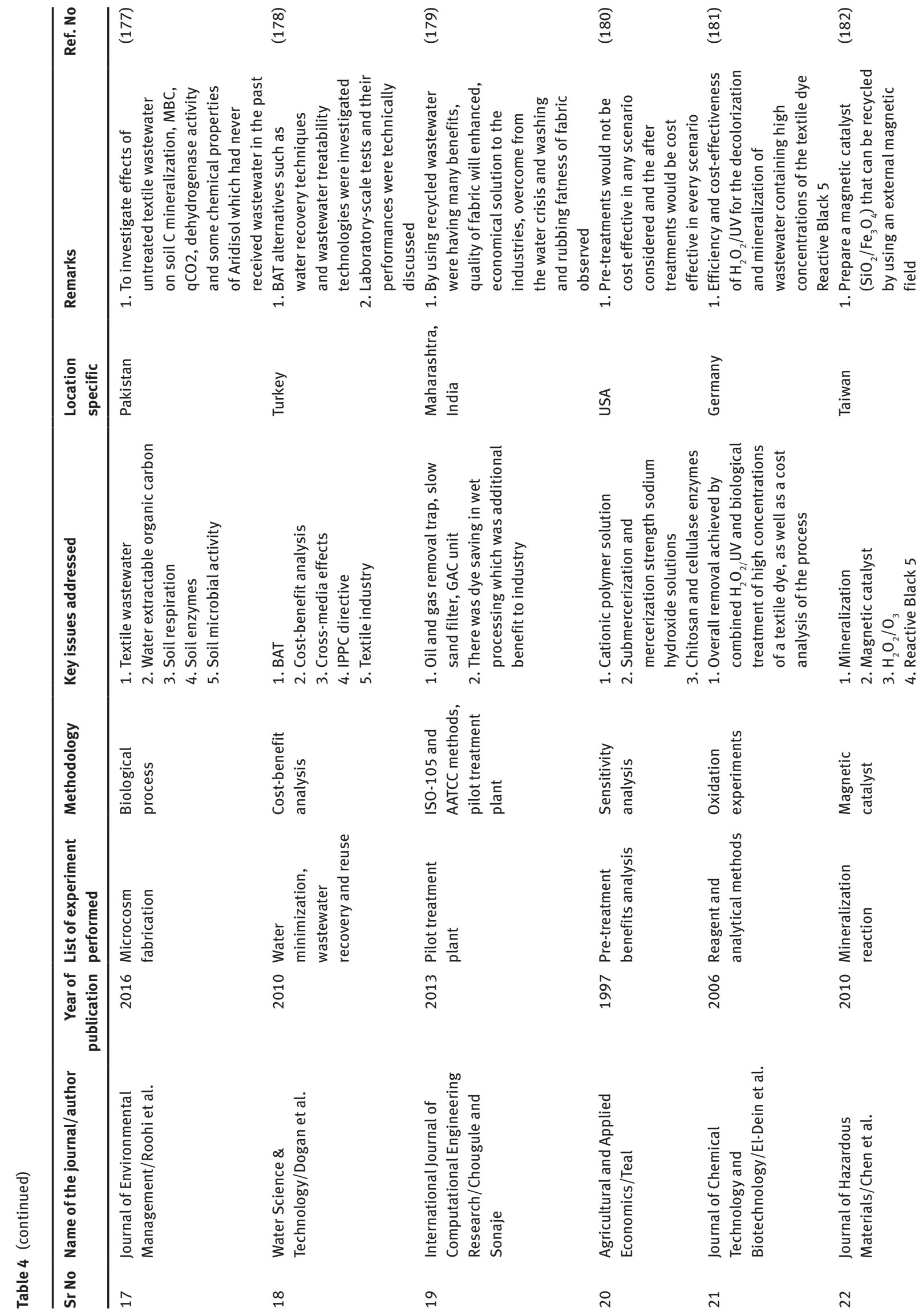




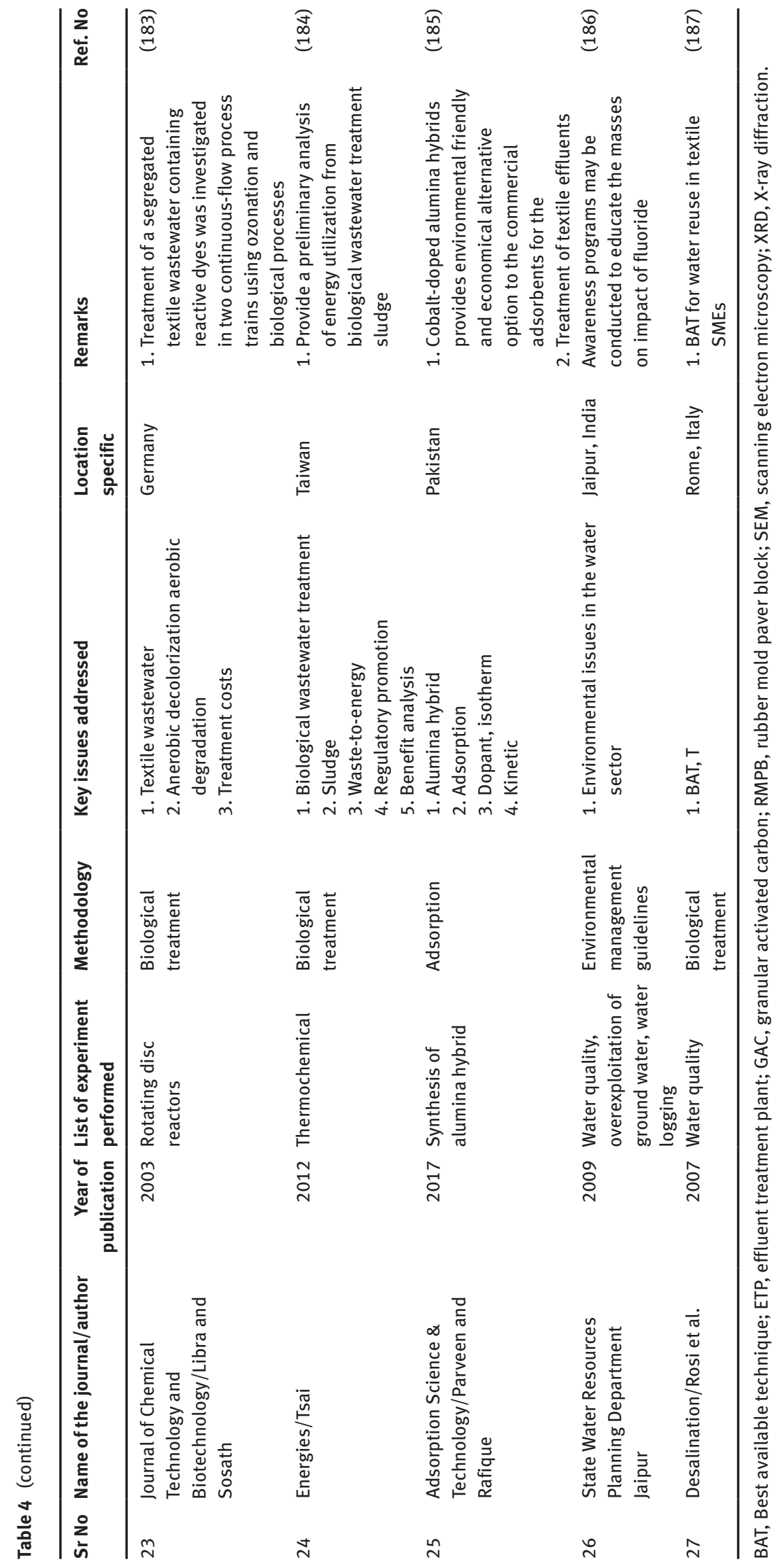




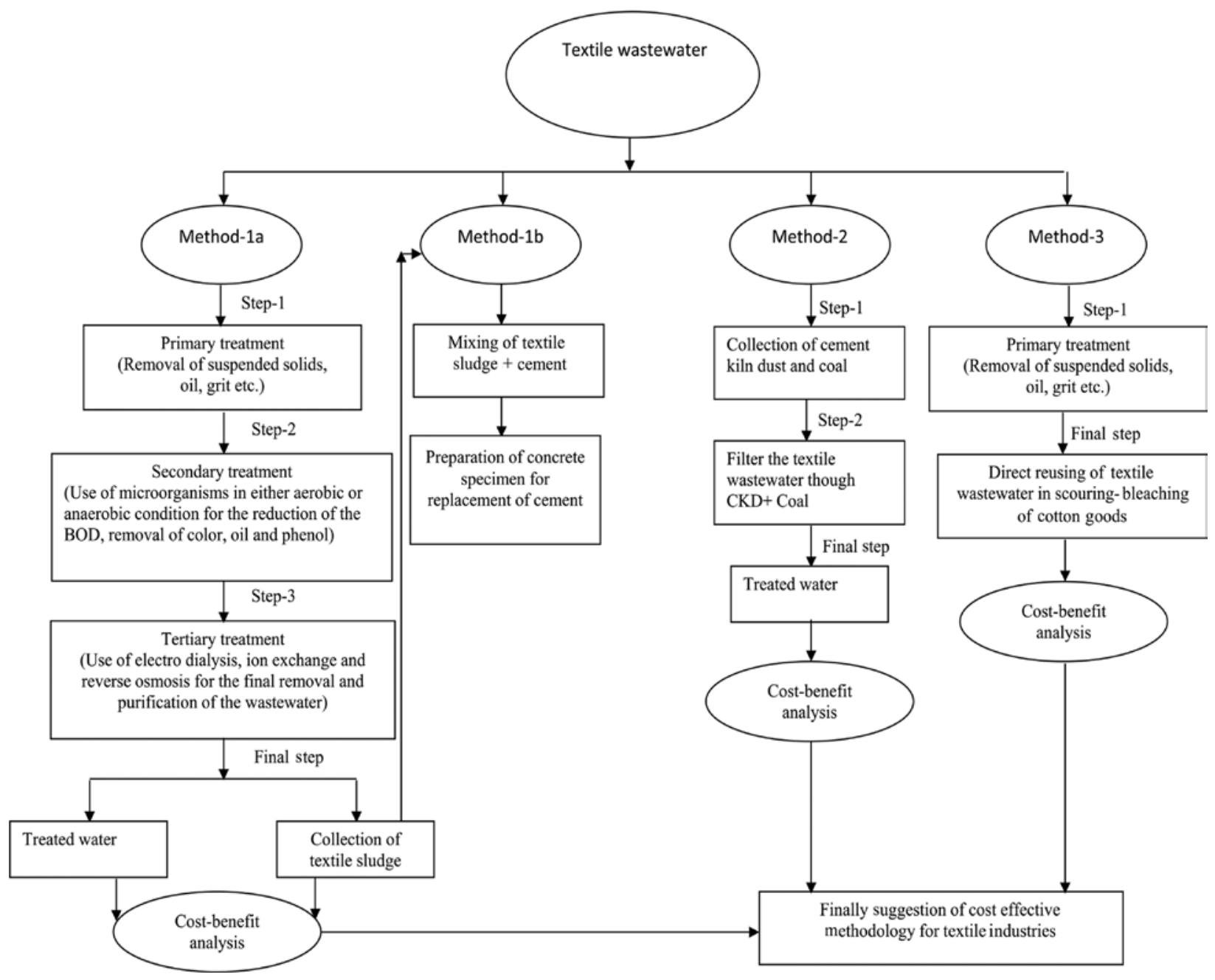

Figure 1: Selection effective treatment technique for textile wastewater

to reduce waste collection and landfill costs, simultaneously these wastes will give direct benefits to consumers and participating enterprises.

\section{Conclusions}

The textile making industry is one of the major industries in India for the growth of the economy as well as employing the unskilled to skilled workers. The textile industry produces a massive quantity of textile wastes in term of chemicals, solid wastes and environment wastes after successful treatment of textile fibers, rinsing of final products, as well as from dyes. The treatment techniques followed in the textile industry are not cost-effective, and therefore, an alternative treatment technique was discussed from the cost-effective point of view. Textile wastewater can cause hemorrhages, ulceration of the skin, sickness, stress and dermatitis. The chemicals present in the water can block sunlight and increase the BOD thereby inhibiting photosynthesis and reoxygenation.

\section{Author Statement}

Research funding: Authors state no funding involved. Conflict of interest: Authors state no conflict of interest. Informed consent: Informed consent is not applicable. Ethical approval: The conducted research is not related to either human or animal use.

\section{References}

1. Banat I, Nigam P, Singh D, Marchant R. Microbial decolorization of textile dye containing effluent: a review. Bioresour Technol 1996;58:217-27.

2. Bakshi DK, Gupta KG, Sharma P. Enhanced biodegradation of synthetic textile dye effluent by Phenerochaete chrysoporium under improved culture. World J Microbiol Biotechnol 1999;15:507-9. 
3. Senan RC, Abraham TE. Bioremediation of textile azo dyes by aerobic bacterial consortium. Biodegradation 2004;15: 275-80.

4. Suman K, Anjali P, Asok A. Utilization of silica gel waste for adsorption of cationic surfactant and adsolubilization of organics from textile wastewater: a case study. Desalination 2011;276:142-7.

5. Antonella A, Barbara P, Federica S, Valeria T, Valeria P, Giovanna $\mathrm{CV}$. Decolourisation and detoxification in the fungal treatment of textile wastewaters from dyeing processes. N Biotechnol 2011;29:38.

6. Iva R. Determination of engineered nanoparticles on textiles and in textile wastewaters. Trends Anal Chem 2011;30:1159.

7. Eliana WM, Eder CL, Betina R, Felipe ES, Bruna DS, José RG, et al. Ionic silica based hybrid material containing the pyridinium group used as an adsorbent for textile dye. J Colloid Interface Sci 2012;378:10-20.

8. Jadhav JP, Kalyani DC, Telke AA, Phugare SS, Govindwar SP. Evaluation of the efficacy of a bacterial consortium for the removal of color, reduction of heavy metals, and toxicity from textile dye effluent. Bioresour Technol 2010;101:165-73.

9. Novotný C, Svobodová K, Benada O, Kofroňová O, Heissenberger A, Fuchs W. Potential of combined fungal and bacterial treatment for color removal in textile wastewater. Bioresour Technol 2011;102:879-88.

10. Jeihanipour A, Karimi K, Niklasson C, Taherzadeh JM. A novel process for ethanol or biogas production from cellulose in blended-fibers waste textiles. Waste Manag 2010;30:2504-9.

11. Foo KY, Hameed BH. Decontamination of textile wastewater via $\mathrm{TiO}_{2} /$ activated carbon composite materials. Adv Colloid Interface Sci 2010;159:130-43.

12. Follansbee DM, Paccione JD, Martin LL. Globally optimal design and operation of a continuous photocatalytic advanced oxidation process featuring moving bed adsorption and draft-tube transport. Ind Eng Chem Res 2008;47:3591-600.

13. Fu PF, Luan Y, Dai XG. Interposition fixing structure of $\mathrm{TiO}_{2}$ film deposited on activated carbon fibers. Trans Nonferrous Met Soc China 2006;16:965-9.

14. Barredo-Damas S, Alcaina-Miranda MI, Bes-Piá A, Iborra-Clar MI, Iborra-Clar A, Mendoza-Roca JA. Ceramic membrane behavior in textile wastewater ultrafiltration. Desalination 2010;250:623-8.

15. Capar G, Yilmaz L, Yetis U. A membrane-based co-treatment strategy for the recovery of printand beck-dyeing textile effluents. J Hazard Mater 2008;152:316-23.

16. De Florio L, Giordano A, Mattioli D. Nanofiltration of low-contaminated textile rinsing effluents for on-site treatment and reuse. Desalination 2005;181:283-92.

17. van der Bruggen B, Lejon L, Vandecasteele C. Industrial process water recycling: principles and examples. Environ Prog 2005;24:417-25.

18. EPA Report, Best management practices for pollution prevention in the textile industry, EPA Manual 625/R-96-004, 1996.

19. Srivastava HP, Arthanareeswaran G, Anantharaman N, Starov VM. Performance of modified poly(vinylidene fluoride) membrane for textile wastewater ultrafiltration. Desalination 2011;282:87-94.

20. Aouni A, Fersi C, Cuartas-Uribe B, Bes-Pía A, Alcaina-Miranda MI, Dhahbi M. Reactive dyes rejection and textile effluent treatment study using ultrafiltration and nanofiltration processes. Desalination 2012;297:87-96.
21. Barredo-Damas S, Alcaina-Miranda MI, Iborra-Clar MI, MendozaRoca JA. Application of tubular ceramic ultrafiltration membranes for the treatment of integrated textile wastewaters. Chem Eng J 2012;192:211-8.

22. Turhan K, Durukan I, Ozturkcan SA, Turgut Z. Decolorization of textile basic dye in aqueous solution by ozone. Dyes Pigm 2012;92:897-901.

23. Ashwin R, Athinthra KS, Sriramvignesh M, Kathiravan MN, Gopinath KP. Treatment of textile effluent using SBR with pre and post treatments: kinetics, simulation and optimization of process time for shock loads. Desalination 2011;275:203-11.

24. Hai Fl, Yamamoto K, Nakajima F, Fukushi K. Bioaugmented membrane bioreactor (MBR) with a GAC-packed zone for high rate textile wastewater treatment. Water Res 2011;45:2199-206.

25. Gnanapragasam G, Senthilkumar M, Arutchelvan V, Velayutham T, Nagarajan S. Bio-kinetic analysis on treatment of textile dye wastewater using anaerobic batch reactor. Bioresour Technol 2011;102:627.

26. Balamurugan B, Thirumarimurugan M, Kannadasan T. Anaerobic degradation of textile dye bath effluent using Halomonas sp. Bioresour Technol 2011;102:6365-9.

27. Papadia S, Rovero G, Fava F, Gioia DD. Comparison of different pilot scale bioreactors for the treatment of a real wastewater from the textile industry. Int Biodeterior Biodegradation 2011;65:396-403.

28. Su CC, Pukdee-Asa M, Ratanatamskul C, Lu MC. Effect of operating parameters on the decolorization and oxidation of textile wastewater by the fluidized-bed Fenton process. Sep Purif Technol 2011;83:100-5.

29. Senthilkumar M, Gnanapragasam G, Arutchelvan V, Nagarajan S. Treatment of textile dyeing wastewater using two-phase pilot plant UASB reactor with sago wastewater as co-substrate. Chem Eng J 2011;166:10-4.

30. Basha CA, Sendhil J, Selvakumar KV, Muniswaran PKA, Lee CW. Electrochemical degradation of textile dyeing industry effluent in batch and flow reactor systems. Desalination 2012;285:188-97.

31. Sapkal RT, Shinde SS, Mahadik MA, Mohite VS, Waghmode TR, Govindwar SP, et al. Photoelectrocatalytic decolorization and degradation of textile effluent using $\mathrm{ZnO}$ thin films. J Photochem Photobiol B Biol 2012;114:102-7.

32. Khouni I, Marrot B, Amar RB. Treatment of reconstituted textile wastewater containing a reactive dye in an aerobic sequencing batch reactor using a novel bacterial consortium. Sep Purif Technol 2012;87:110-9.

33. Nahil MA, Williams PT. Surface chemistry and porosity of nitrogen-containing activated carbons produced from acrylic textile waste. Chem Eng J 2012;184:228-37.

34. Khlifi R, Belbahri L, Woodward S, Ellouz M, Dhouib A, Sayadi $S$, et al. Decolourization and detoxification of textile industry wastewater by the laccase-mediator system. J Hazard Mater 2010;175:802-8.

35. Khouni I, Marrot B, Moulin P, Amar RB. Decolourization of the reconstituted textile effluent by different process treatments: enzymatic catalysis, coagulation/flocculation and nanofiltration processes. Desalination 2011;268:27-37.

36. Qadeer R. Adsorption behavior of ruthenium ions on activated charcoal from nirtic acid medium. Colloids Surf A 2007;293:217-23.

37. Cengiz S, Tanrikulu F, Aksu S. An alternative source of adsorbent for the removal of dyes from textile waters: Posidonia oceanica (L.) Chem Eng J 2012;189-90:32-40. 
38. Merzouk B, Yakoubi M, Zongo I, Leclerc JP, Paternotte G, Pontvianne S, et al. Effect of modification of textile wastewater composition on electrocoagulation efficiency. Desalination 2011;275:181-6.

39. Naje AS, Chelliapan S, Zakaria Z, Ajeel MA, Alaba PA. A review of electrocoagulation technology for the treatment of textile wastewater. Rev Chem Eng 2017;33:263-92.

40. Chen X, Chen G, Yue PL. Separation of pollutants from restaurant wastewater by electrocoagulation. Sep Purif Technol 2000;19:65-76.

41. Naje AS, Chelliapan S, Zakaria Z, Abbas SA. Treatment performance of textile wastewater using electrocoagulation (EC) process under combined electrical connection of electrodes. Int J Electrochem Sci 2015;10:5924-41.

42. Golder AK, Samantha AN, Ray S. Removal of $\mathrm{Cr}^{3+}$ by electrocoagulation with multiple electrodes: bipolar and monopolar configurations. J Hazard Mater 2007;141:653-61.

43. Heidman I, Calmano W. Removal of $\mathrm{Cr}(\mathrm{VI})$ from model wastewaters by electrocoagulation with Fe electrode. Sep Purif Technol 2008;61:15-21.

44. Merzouk B, Madani K, Sekki A. Treatment characteristics of textile wastewater and removal of heavy metals using the electroflotation technique. Desalination 2008;228:245-54.

45. Merzouk B, Gourich B, Sekki A, Madani K, Chibane M. Removal turbidity and separation of heavy metals using electrocoagulation-electroflotation technique: a case study. J Hazard Mater 2009;164:215-22.

46. Meunier N, Drogui P, Montané C, Hausler R, Mercier G, Blais JF. Comparison between electrocoagulation and chemical precipitation for metals removal from acidic soil leachate. J Hazard Mater 2006;137:581-90.

47. Heidmann I, Calmano W. Removal of $\mathrm{Zn}(\mathrm{II}), \mathrm{Cu}(\mathrm{II}), \mathrm{Ni}(\mathrm{II}), \mathrm{Ag}(\mathrm{I})$ and $\mathrm{Cr}(\mathrm{VI})$ present in aqueous solutions by aluminium electrocoagulation. J Hazard Mater 2008;152:934-41.

48. Canizares P, Martınez F, Jimenez C, Saez C, Rodrigo MA. Coagulation and electrocoagulation of oil-in-water emulsions. J Hazard Mater 2008;151:44-51.

49. Khemis M, Tanguy G, Leclerc JP, Valentin G, Lapicque F. Electrocoagulation for the treatment of oil suspensions: relation between the electrode generations and the waste content. Process Saf Environ Prot 2005;83:50-7.

50. Kobya M, Can TO, Bayramoglu M. Treatment of textile wastewaters by electrocoagulation using iron and aluminium electrodes. J Hazard Mater B 2003;100:163-78.

51. Alinsafi A, Khemis M, Pons MN, Leclerc JP, Yaacoubi A, Benhammou A, et al. Electrocoagulation of reactive textile dyes and textile wastewaters. Chem Eng Process 2005;44: 461-70.

52. Merzouk B, Gourich B, Sekki A, Madani K, Vial C, Barkaoui M. Studies on the decolorization of textile dye wastewater by continuous electrocoagulation process. Chem Eng J 2009;149:207-14.

53. Zongo I, Maïga A, Wéthé J, Valentin G, Paternotte G, Leclerc JP, et al. Electrocoagulation for the treatment of textile wastewaters with Al or Fe electrodes: compared variations of COD levels, turbidity and absorbance. J Hazard Mater 2009;169:70-6.

54. Daneshvar N, Oladegaragoze A, Djafarzadeh N. Decolorization of basic dye solutions by electrocoagulation: an investigation of the effect of operational parameters. J Hazard Mater 2006;129:116-22.
55. Bensadok K, Benammar S, Lapicque F, Nezzal G. Electrocoagulation of cutting oil emulsions using aluminium plate electrodes. J Hazard Mater 2008;152:423-30.

56. Merzouk B, Madani K, Sekki A. Using electrocoagulationelectroflotation technology to treat synthetic solution and textile wastewater, two case studies. Desalination 2010;250:573-7.

57. Sánchez-Martín J, Beltrán-Heredia J, Solera-Hernández C. Surface water and wastewater treatment using a new tannin-based coagulant: pilot plant trials. J Environ Manage 2010;91:2051-8.

58. Zidane F, Drogui P, Lekhlif B, Bensaid J, Blais JF, Belcadi S. Decolourization of dye-containing effluent using mineral coagulants produced by electrocoagulation. J Hazard Mater 2008;155:153-63.

59. Maljaei A, Arami M, Mahmoodi NM. Decolorization and aromatic ring degradation of colored textile wastewater using indirect electrochemical oxidation method. Desalination 2009;249:1074-8.

60. Nidheesh PV, Gandhimathi R. Trends in electro-Fenton process for water and wastewater treatment: an overview. Desalination 2012;299:1-15.

61. Barrera-Diaz C, Roa-Morales G, AA vila-Cordoba L, Pavon-Silva T, Bilyeu B. Electrochemical treatment applied to food-processing industrial wastewater. Ind Eng Chem Res 2006;45:34-8.

62. Gomes JAG, Daida P, Kesmez M, Weir M, Moreno H, Parga JR. Arsenic removal by electrocoagulation using combined Al-Fe electrode system and characterization of products. J Hazard Mater 2007;139:220-31.

63. Keshmirizadeh E, Yousefi S, Rofouei MK. An investigation on the new operational parameter effective in $\mathrm{Cr}(\mathrm{VI})$ removal efficiency: a study on electrocoagulation by alternating pulse current. J Hazard Mater 2011;190:119-24.

64. Shafaei A, Pajootan E, Nikazar M, Arami M. Removal of Co (II) from aqueous solution by electrocoagulation process using aluminum electrodes. Desalination 2011;279:121-6.

65. Maria V. Tailoring fly ash activated with bentonite as adsorbent for complex wastewater treatment. Appl Surf Sci 2012;263: 753-62.

66. Drouiche N, Aoudj S, Hecini M, Ouslimane T. Experimental design for the elimination of fluoride from pretreated photovoltaic wastewater by electrocoagulation. Chem Eng Trans 2011;24:1207-12.

67. Yilmaz AE, Boncukcuoğlu R, Kocakerim M, Karakaş İH. Waste utilization: the removal of textile dye (Bomaplex Red CR-L) from aqueous solution on sludge waste from electrocoagulation as adsorbent. Desalination 2011;277:156-63.

68. Verma AK, Dash RR, Bhunia P. A review on chemical coagulation/flocculation technologies for removal of colour from textile wastewaters. J Environ Manage 2012;93:154-68.

69. Qi L, Wang X, Xu Q. Coupling of biological methods with membrane filtration using ozone as pre-treatment for water reuse. Desalination 2011;270:264-8.

70. Liu M, Lü Z, Chen Z, Yu S, Gao C. Comparison of reverse osmosis and nanofiltration membranes in the treatment of biologically treated textile effluent for water reuse. Desalination 2011;281:372-8.

71. Jedidi I, Khemakhem S, Saïdi S, Larbot A, Elloumi-Ammar $\mathrm{N}$, Fourati A, et al. Preparation of a new ceramic microfiltration membrane from mineral coal fly ash: application to the treatment of the textile dying effluents. Powder Technol 2011;208:427-32. 
72. Ellouze E, Tahri N, Amar RB. Enhancement of textile wastewater treatment process using nanofiltration. Desalination 2012;286:16-23.

73. Borsi I, Caretti C, Fasano A, Heijnen M, Lubello C. Optimization of hollow fibers membrane wastewater treatment: an experimental study. Desalination 2012;302:80-6.

74. Cheng S, Oatley DL, Williams PM, Wright CJ. Characterisation and application of a novel positively charged nanofiltration membrane for the treatment of textile industry wastewaters. Water Res 2012;46:33-42.

75. Robinson T, McMullan G, Marchant R, Nigam P. Remediation of dyes in textile effluent: a critical review on current treatment technologies with a proposed alternative. Bioresour Technol 2001;77:247-55.

76. Körbahti BK, Artut K, Gel CG, Özer A. Electrochemical decolorization of textile dyes and removal of metal ions from textile dye and metal ion binary mixtures. Chem Eng J 2011;173:677-88.

77. Parsa JB, Rezaei M, Soleymani AR. Electrochemical oxidation of an azo dye in aqueous media investigation of operational parameters and kinetics. J Hazard Mater 2009;168:997-1003.

78. Tamboli DP, Kurade M, Waghmode TR, Joshi SM, Govindwar SP. Exploring the ability of Sphingobacterium sp. ATM to degrade textile dye Direct Blue GLL, mixture of dyes and textile effluent and production of polyhydroxyhexadecanoic acid using waste biomass generated after dye degradation. J Hazard Mater 2010;182:169-76.

79. Sathishkumar P, Arulkumar M, Palvannan T. Utilization of agroindustrial waste Jatropha curcas pods as an activated carbon for the adsorption of reactive dye Remazol Brilliant Blue R (RBBR). J Clean Prod 2012;22:67-75.

80. Yang Q, Wang J, Wang H, Chen X, Ren S, Li X, et al. Evolution of the microbial community in a full-scale printing and dyeing wastewater treatment system. Bioresour Technol 2012;117: 155-63.

81. Armagan B. Factors affecting the performances of sepiolite and zeolite for the treatment of textile wastewater. J Environ Sci Health A Tox Hazard Subst Environ Eng 2003;38:883-96.

82. Armağan B, Ozdemir O, Turan M, Celik MS. The removal of reactive azo dyes by natural and modified zeolites. I Chem Technol Biotechnol 2003;78:725-32.

83. Deng DY, Guo J, Zeng GQ, Sun GP. Decolorization of anthraquinone, triphenylmethane and azo dyes by a new isolated Bacillus cereus strain DC11. Int Biodeterior Biodegradation 2008;62:263-9.

84. Garg SK, Tripathi M, Singh SK, Tiwari JK. Biodecolorization of textile dye effluent by Pseudomonas putida SKG-1 (MTCC 10510) under the conditions optimized for monoazo dye orange II color removal in simulated minimal salt medium. Int Biodeterior Biodegradation 2012;74:24-35.

85. El-Sheekh MM, Gharieb MM, Abou-El-Souod GW. Biodegradation of dyes by some green algae and cyanobacteria. Int Biodeterior Biodegradation 2009;63:699-704.

86. Senthilkumar S, Ahmed Basha C, Perumalsamy M, Prabhu HJ. Electrochemical oxidation and aerobic biodegradation with isolated bacterial strains for dye wastewater: combined and integrated approach. Electrochimica Acta 2012;77:171-8.

87. Vergili I, Kaya Y, Sen U, Gönder ZB, Aydiner C. Techno-economic analysis of textile dye bath wastewater treatment by integrated membrane processes under the zero liquid discharge approach. Resour Conserv Recycl 2012;58:25-35.
88. Carliell CM, Barclay SJ, Naidoo N, Buckley CA, Mulholland DA, Senior E. Microbial decolourization of a reactive azo dye under anaerobic conditions. Water SA 1995;21:61-9.

89. Heiss GS, Gowan B, Dabbs ER. Cloning of DNA from a Rhodococcus strain conferring the ability to decolorize sulfonated aze dyes. FEMS Microbiol Lett 1992;99:221-6.

90. Eichlerova I, Homolka L, Nerud F. Synthetic dye decolorization capacity of white rot fungus Dichomitus squalens. Bioresour Technol 2006;97:2153-9.

91. Tan L, Qu YY, Zhou JT, Ma F, Li A. Dynamics of microbial community for X-3B wastewater decolorization coping with high-salt and metal ions conditions. Bioresour Technol 2009;100:3003-9.

92. Cui D, Li G, Zhao D, Gu X, Wang C, Zhao M. Microbial community structures in mixed bacterial consortia for azo dye treatment under aerobic and anaerobic conditions. J Hazard Mater 2012;221-222:185-92.

93. de Souza AAU, Melo AR, Pessoa FL, de Souza SMAGU. The modified water source diagram method applied to reuse of textile industry continuous washing water. Resour Conserv Recycl 2010;54:1405-11.

94. Rajaguru P, Kalaiselvi K, Palanivel M, Subburam V. Biodegradation of azo dyes in a sequential anaerobiceaerobic system. Appl Microbiol Biotechnol 2000;54:268-73.

95. Verma P, Madamwar D. Decolorization of synthetic dyes by newly isolated strain of Serratia marcescens. World J Microbiol Biotechnol 2003;19:615-8.

96. Adedayo O, Javadpour S, Tylor C, Anderson WA, Moo-Young M. Decolourization and detoxification of methyl red by aerobic bacteria from waste water treatment plant. World J Microbiol Biotechnol 2004;20:545-50.

97. Eren Z. Ultrasound as a basic and auxiliary process for dye remediation: a review. J Environ Manage 2012;104:127-41.

98. Liou RM, Chen SH, Hung MY, Hsu CS, Lai JY. Fe (III) supported on resin as effective catalyst for the heterogeneous oxidation of phenol in aqueous solution. Chemosphere 2005;59:117-21.

99. Kong L, Lemley AT. Kinetic modeling of 2,4-D degradation in soil slurry by anodic Fenton treatment. J Agric Food Chem 2006;54:3941-4.

100. Sarwan B, Pare B, Acharya AD, Jonnalagadda SB. Mineralization and toxicity reduction of textile dye neutral red in aqueous phase using BiOCl photocatalysis. J Photochem Photobiol B 2012;116:48-55.

101. Karthikeyan S, Titus A, Gnanamani A, Mandal AB, Sekaran G. Treatment of textile wastewater by homogeneous and heterogeneous Fenton oxidation processes. Desalination 2011;281:438-45.

102. Salazar R, Brillas E, Sirés I. Finding the best $\mathrm{Fe}^{2+} / \mathrm{Cu}^{2+}$ combination for the solar photoelectro-Fenton treatment of simulated wastewater containing the industrial textile dye Disperse Blue 3. Appl Catal B Environ 2012; 115-116:107-16.

103. Kochany J, Lipczynska-Kochany E. Utilization of landfill leachate parameters for pretreatment by Fenton reaction and struvite precipitation - a comparative study. J Hazard Mater 2009;166:248-54.

104. Ali NF, El-Mohamedy RSR. Microbial decolourization of textile waste water. J Saudi Chem Soc 2012;16:117-23.

105. Solís M, Solis A, Perez HI, Manjarrez N, Maribel F. Microbial decolouration of azo dyes: a review. Process Biochem 2012;47:1723-48. 
106. Kusic H, Koprivanac N, Bozic AL. Minimization of organic pollutant content in aqueous solution by means of AOPs. UV and ozone based technologies. J Chem Eng 2006;123: 127-37.

107. Hai FI, Yamamoto K, Fukushi K. Hybrid treatment systems for dye wastewater. Crit Rev Environ Sci Technol 2007;37:315-77.

108. Wu CH, Chang CL. Decolorization of reactive red 2 by advanced oxidation processes: comparative studies of homogeneous and heterogeneous systems. J Hazard Mater B 2006;128:265-72.

109. Wang S, Peng Y. Natural zeolites as effective adsorbents in water and wastewater treatment. Chem Eng J 2010;156:11-24.

110. Hedström A, Amofah LR. Adsorption and desorption of ammonium by clinoptilolite adsorbent in municipal wastewater treatment systems. J Environ Eng Sci 2008;7:53-61.

111. Panayotova MI. Kinetics and thermodynamics of copper ions removal from wastewater by use of zeolite. Waste Manage 2001;21(7):671-6.

112. Panayotova M. Use of zeolite for cadmium removal from wastewater. J Environ Sci Health A Tox Hazard Subst Environ Eng 2000;35:1591-601.

113. Panayotova M, Velikov B. Kinetics of heavy metal ions removal by use of natural zeolite. J Environ Sci Health A Tox Hazard Subst Environ Eng 2002;37:139-47.

114. Amin NK. Removal of reactive dye from aqueous solutions by adsorption onto activated carbons prepared from sugarcane bagasse pith. Desalination 2008;223:152-61.

115. Gupta VK, Ali I, Mohan D. Equilibrium uptake and sorption dynamics for the removal of a basic dye using low-cost adsorbents. J Colloid Interface Sci 2003;265:257-64.

116. Barka N, Assabbane A, Nounah A, Laanab L, Ichou YA. Removal of textile dyes from aqueous solutions by natural phosphate as a new adsorbent. Desalination 2009;235(1-3):264-75.

117. Mittal A, Krishnan L, Gupta VK. Use of waste materials-bottom ash and de-oiled soya, as potential adsorbents for the removal of amaranth from aqueous solutions. J Hazard Mater 2005;117:171-8.

118. Mittal A. Use of hen feathers as potential adsorbent for the removal of a hazardous dye, Brilliant Blue FCF, from wastewater. J Hazard Mater 2006;128:233-9.

119. Panayotova M, Velikov B. Influence of zeolite transformation in a homoionic form on the removal of some heavy metal ions from wastewater. J Environ Sci Health A Tox Hazard Subst Environ Eng 2003;38:545-54.

120. Lian L, Guo L, Wang A. Use of $\mathrm{CaCl}_{2}$ modified bentonite for removal of Congo red dye from aqueous solutions. Desalination 2009;249(2):797-801.

121. Özcan AS, Erdem B, Özcan A. Adsorption of Acid Blue 193 from aqueous solutions onto $\mathrm{Na}$-bentonite and DTMA-bentonite. J Colloid Interface Sci 2004;280:44-54.

122. Özcan AS, Tetik S, Özcan A. Adsorption of acid dyes from aqueous solutions onto sepiolite. Sep Sci Technol 2004;39: 301-20.

123. Sohrabnezhad S, Pourahmad A. Comparison absorption of new methylene blue dye in zeolite and nanocrystal zeolite. Desalination 2010;256(1-3):84-9.

124. Souther RH, Alspaugh TA. Textile wastes: recovery and treatment. Sewage Ind Waste 1957;29:918-35.

125. Tsantaki E, Velegraki T, Katsaounis A, Mantzavinos D. Anodic oxidation of textile dyehouse effluents on boron-doped diamond electrode. J Hazard Mater 2012;207-208:91-6.
126. Martellini T, Jones KC, Sweetman A, Giannoni M, Pieri F, Cincinelli $A$. The contribution of waste water treatment plants to PBDEs in ambient air. Environ Pollut 2012;169:242-7.

127. Loncar N, Janovic B, Vujcic M, Vujci Z. Decolorization of textile dyes and effluents using potato (Solanum tuberosum) phenoloxidase. Int Biodeterior Biodegradation 2012;72:42-5.

128. Kurade MB, Waghmode TR, Kagalkar AN, Govindwar SP. Decolorization of textile industry effluent containing disperse dye Scarlet RR by a newly developed bacterial-yeast consortium BL-GG. Chem Eng J 2012;184:33-41.

129. Derden A, Huybrechts D. Brominated flame retardants in textile wastewater: reducing Deca-BDE using best available techniques. J Clean Prod 2013;53:167-75.

130. Joint Research Centre, 2003. IPPC Reference Document on Best Available Techniques for the Textiles Industry. http://eippcb. jrc.es/reference/BREF/txt_bref_0703.pdf.

131. Mahmoued EK. Cement kiln dust and coal filters treatment of textile industrial effluents. Desalination 2010;255:175-8.

132. Saraya MEl-SI, Aboul-Fetouh MEIS. Utilization from cement kiln dust in removal of acid dyes. Am J Environ Sci 2012;8(1):16-24.

133. Mostafa HM, Rashed EM, Mostafa AH. Utilization of By-Pass Kiln Dust for Treatment of Tanneries Effluent Wastewater. Ninth International Water Technology Conference, IWTC9 2005, Sharm El-Sheikh, Egypt, 2005:133-41.

134. Mackie A, Boilard S, Walsh ME, Lake CB. Physicochemical characterization of cement kiln dust for potential reuse in acidic wastewater treatment. J Hazard Mater 2010;173:283-91.

135. Saraya MEl-SI, Nassar HS. Removal of Reactive Blue7 dye from aqueous solution using solid waste. Int J Res Eng Technol 2015;3(7):19-36.

136. Bazin I, Hassine AH, Hamouda YH, Mnif W, Bartegi A, LopezFerber M, et al. Estrogenic and anti-estrogenic activity of 23 commercial textile dyes. Ecotoxicol Environ Saf 2012;85:131-6.

137. Shaheen SM, Eissa FI, Ghanem KM, El-Din HMG, Anany FSAl. Metal ion removal from wastewaters by sorption on activated carbon, cement kiln dust, and sawdust. Water Environ Res 2015;87(6):506-15.

138. Srivastava VC, Mall ID, Mishra IM. Adsorption thermodynamics and isosteric heat of adsorption of toxic metal ions onto bagasse fly ash (BFA) and rice husk ash (RHA). Chem Eng J 2007;132:267-78.

139. Li YC, Chu CY, Wu SY, Tsai CY, Wang CC, Hung CH, et al. Feasible pretreatment of textile wastewater for dark fermentative hydrogen production. Int J Hydrog Energy 2012;37:15511-7.

140. Mahmoud DK, Salleh MAM, Abdul Karim WAW, Idris A, Abidin ZZ. Batch adsorption of basic dye using acid treated kenaf fibre char: equilibrium, kinetic and thermodynamic studies. Chem Eng J 2012;181-182:449-57.

141. Allen SJ. Equilibrium adsorption isotherms for peat. Fuel 1987;66:1171-5.

142. Allen SJ, Gan Q, Matthews R, Johnson PA. Comparison of optimised isotherm models for basic dye adsorption by kudzu. Bioresour Technol 2003;88:143-52.

143. Mui ELK, Cheung WH, McKay G. Tyre char preparation from waste tyre rubber for dye removal from effluents. J Hazard Mater 2010;175:151-8.

144. Kadam AA, Telke AA, Jagtap SS, Govindwar SP. Decolorization of adsorbed textile dyes by developed consortium of Pseudomonas sp. SUK1 and Aspergillus ochraceus NCIM-1146 under solid state fermentation. J Hazard Mater 2011;189:486-94. 
145. Ip AWM, Barford JP, McKay G. A comparative study on the kinetics and mechanisms of removal of Reactive Black 5 by adsorption onto activated carbons and bone char. Chem Eng J 2010;157:434-42.

146. Dizge N, Aydiner C, Demirbas E, Kobya M, Kara S. Adsorption of reactive dyes from aqueous solutions by fly ash: kinetic and equilibrium studies. J Hazard Mater 2008;150:737-46.

147. Sun D, Zhang X, Wu Y, Liu X. Adsorption of anionic dyes from aqueous solution on fly ash. J Hazard Mater 2010;181:335-42.

148. El-Refaey AA. Comparative performance of cement kiln dust and activated carbon in removal of cadmium from aqueous solutions. Water Sci Technol 2016;73(7):1691-9.

149. ElRefaey AA. Investigation of copper removal from aqueous solution by cement kiln dust as industrial by-product. Alexandria Sci Exchange J 2017;38(1):149-58.

150. Kumar KV, Porkodi K. Equilibrium and thermodynamics of dye removal from aqueous solution by adsorption using rubber wood saw dust. Int J Environ Tech Manag 2009;10(3/4): 295-307.

151. Malik PK. Use of activated carbons prepared from sawdust and rice-husk for adsorption of acid dyes: a case study of Acid Yellow 36. Dyes Pigm 2003;56:239-49.

152. Charumathi D, Das N. Packed bed column studies for the removal of synthetic dyes from textile wastewater using immobilised dead C. tropicalis. Desalination 2012;285:22-30.

153. Chuah TG, Jumasiah A, Azni I, Katayon S, Choong SYT. Rice husk as a potentially low-cost biosorbent for heavy metal and dye removal: an overview. Desalination 2005;175:305-16.

154. Wong KK, Lee CK, Low KS, Haron MJ. Removal of Cu and Pb by tartaric acid modified rice husk from aqueous solutions. Chemosphere 2003;50:23-8.

155. Kara S, Aydiner C, Demirbas E, Kobya M, Dizge N. Modeling the effects of adsorbent dose and particle size on the adsorption of reactive textile dyes by fly ash. Desalination 2007;212:282-93.

156. Sebastiano R, Contiello N, Senatore S, Righetti PG, Citterio A. Analysis of commercial Acid Black 194 and related dyes by micellar electrokinetic chromatography. Dyes Pigm 2012;94:258-65.

157. Lin JX, Zhan SL, Fang MH, Qian XQ, Yang H. Adsorption of basic dye from aqueous solution onto fly ash. J Environ Manage 2008;87:193-200.

158. Ferrero F. Dye removal by low cost adsorbents: hazelnut shells in comparison with wood sawdust. J Hazard Mater 2007;142:144-52.

159. Ong ST, Keng PS, Lee CK. Basic and reactive dyes sorption enhancement of rice hull through chemical modification. Am J Appl Sci 2010;7(4):447-52.

160. Lekshmi S, Sasidharan S. Experimental investigation on the use of textile sludge in concrete. Inter J Advan Eng Technol 2015;8(4):559-65.

161. Kulkarni GJ, Dwivedi AK, Jahgirdar SS. Textile mill sludge as fine aggregate in concrete. Global J Res Eng Indus Eng 2012;12(2):12-5.

162. Balasubramanian J, Sabumon PC, Lazar JU, Ilangovan R. Reuse of textile effluent treatment plant sludge in building materials. Waste Manage 2006;26:22-8.

163. Rahman MdM, Khan MdMR, Uddin MdT, Islam MdA. Textile effluent treatment plant sludge: characterization and utilization in building materials. Arab J Sci Eng 2017;42:1435-42.
164. Sudheesh C, Kumar TRP, Kumar S. Effect of compressive strength on concrete by partial replacement of cement with textile sludge and polypropylene fibres. Int J ChemTech Res 2015;8(4):2219-26.

165. Raghunathan T, Gopalsamy P, Elangovan R. Study on strength of concrete with ETP sludge from dyeing industry. Int J Civ Struct Eng 2010;1(3):379-89.

166. Shivanath G, Arumugam E, Murugesan V. Utilization of industrial effluent treatment plant (ETP) sludge as partial replacement for cement in concrete. Jr Ind Poll Cont 2011;27(1):33-8.

167. Weng CH, Lin DF, Chiang PC. Utilization of sludge as brick materials. Adv Environ Res 2003;7:679-85.

168. Sayyad K, Bhagat A, Chaugule N, Amolsaratkar, Umesh D. Compressive Strength of Concrete Binderded with Textile Fibre Waste and Waste Plaster of Paris. 5th International Conference on Recent Trends in Engineering, Science and Management, Parvatibai Genba Moze College of Engineering, Wagholi, Pune, 2016.

169. Patel K, Patel RL, Pitroda J. Technical feasibility study on utilization of textile sludge as a cement substitute in rubber mould paver block. Intern J Constructive Res Civil Eng (IJCRCE) 2017;3(1):19-25.

170. Patel H, Pandey S. Exploring the reuse potential of chemical sludge from textile wastewater treatment plants in India - a hazardous waste. Am J Environ Sci 2009;5(1):106-10.

171. Patel H, Pandey S. Evaluation of physical stability and leachability of Portland Pozzolona Cement (PPC) solidified chemical sludge generated from textile wastewater treatment plants. J Hazard Mater 2012;207-208:56-64.

172. Sahu V, Sohoni P, Dave N, Verma I. Utilization of industrial byproduct as raw material in construction industry - a review. Intern J Eng Sci Technol 2013;5(2):242-6.

173. Reis JMLd. Effect of textile waste on the mechanical properties of polymer concrete. Mat Res 2009;12(1):63-7.

174. Kaur H, Singh J, Khattra SK. The workability and compressive strength of concrete using textile mill sludge and plasticizer. I Jl Civil, Structural, Environl Infrastructure Eng Research Dev 2017;7(4):1-8.

175. Shaid A, Osman MdS, Hannan MdA, Bhuiyan MAR. Direct reusing of textile wastewater in scouring-bleaching of cotton goods devoid of any treatment. Intern J Eng Res Dev 2013;5(8):45-54.

176. Erdumlu N, Ozipek B, Yilmaz G, Topatan Z. Reuse of effluent water obtained in different textile finishing processes. AUTEX Res J 2012;12(1):23-8.

177. Roohi M, Riaz M, Arif MS, Shahzad SM, Yasmeen T, Riaz MA, et al. Varied effects of untreated textile wastewater onto soil carbon mineralization and associated biochemical properties of a dryland agricultural soil. J Environ Manage 2016;183:530-40.

178. Dogan B, Kerestecioglu M, Yetis U. Assessment of the bestavailable wastewater management techniques for a textile mill: cost and benefit analysis. Water Sci Technol 2010;61(4):963-70.

179. Chougule MB, Sonaje NP. Cost- benefit analysis of wastewater recycling plant for textile wet processing. Intern J Comput Eng Re2013;3(1):27-31.

180. Teal SG. Economic analysis of cotton textile finishing processes. Agri Appl Econ, Texas Tech University, 1997.

181. El-Dein AM, Libra J, Wiesmann U. Cost analysis for the degradation of highly concentrated textile dye wastewater with chemical oxidation $\mathrm{H}_{2} \mathrm{O}_{2} / \mathrm{UV}$ and biological treatment. J Chem Technol Biotechnol 2006;81:1239-45. 
182. Chen HW, Kuo YL, Chiou CS, You SW, Ma CM, Chang CT. Mineralization of reactive black 5 in aqueous solution by ozone/ $\mathrm{H} 2 \mathrm{O} 2$ in the presence of magnetic catalyst. J Hazard Mater 2010;174:795-800.

183. Libra J, Sosath F. Combined of biological and chemical processes for the treatment of textile wastewater containing reactive dyes. J Chem Tech Biotech 2003;78:1149-56.

184. Tsai WT. An analysis of the use of biosludge as an energy source and its environmental benefits in Taiwan. Energies 2012;5:3064-73.
185. Parveen K, Rafique U. Development of cobalt-doped alumina hybrids for adsorption of textile effluents. Adsorpt Sci Technol 2018;36(1-2):182-97.

186. Environmental Management Guidelines and Action Plan of SWRPD for Water Sector in Rajasthan (Under Rajasthan Water Sector Restructuring Project), 2009 and 2013, State Water Resources Planning Department, Government of Rajasthan.

187. Rosi OL, Casarci M, Mattioli D, De Florio L. Best available technique for water reuse in textile SMEs (BATTLE LIFE Project). Desalination 2007;206:614-9. 